\title{
Молодые национальные школы XX века - социокультурные и профессиональные парадигмы формирования архитектуры столиц. Зарубежная практика
}

\author{
Е.Г.Малиновская, художественная галерея «АRK», Алматы, Казахстан
}

Современный этап развития мировой культуры отмечен процессом интенсивного формирования молодых национальных школ. Особый интерес вызывают те, что пришли к профессиональному творчеству в XX веке на основе взаимоадаптации культур различного типа: Запад - Восток, профессиональное - народное, современное - фольклорное. Не простая констатация архитектурной хроники, но определение закономерностей такого рода взаимовлияний с учётом параметров конкретной этнокультурной ситуации, имеет первостепенное значение. Подобная творческая парадигма пока не была предметом исследования. В процессе становления современных национальных школ данная концепция приобретает особую весомость в процессе изучения специфики строительства новых столиц зарубежных государств или же реконструкции имеющихся, как это было в Центральной Азии ${ }^{1}$. Анализ практики позволил обозначить возможные варианты творческих моделей: приоритет профессиональных или историко-культурных систем координат, в идеале - их баланс. Примеры данных явлений определили выбор материала статьи. Он характеризует основные факторы сложения столиц Австралии, Индии, Бразилии и республик Советского Востока², выявляя их миссию в динамике самоопределения архитектуры этих стран. Обозначены основные аспекты проектирования в синтезе с наследием или футуристическом диссонансе с ним выдающихся зодчих Ле Корбюзье, 0. Нимейера, архитектурных концепций А.С. Косинского для Ташкента. Дан обзор проектов европейского и русского авангарда начала XX века, трансформировавших центральноазиатские традиции как оседлой, так и кочевой архитектуры. Исследованы примеры, отражающие специфику работы инонациональных архитекторов-профессионалов в историко-культурной среде региона, их роли в становлении национальной идентичности школ. Обозначен вклад зарубежных и советских зодчих в мировое наследие модернизма в контексте поставленных автором задач³.

Ключевые слова: молодые национальные школы, новые столицы, профессиональная культура, инонациональный опыт, традиции, инновации, западно-восточный синтез, проекты русского авангарда для Центральной Азии, мастера модернизма послевоенных десятилетий.
Young National Schools of the XX Century - Socio-Cultural and Professional Paradigms for Forming the Capital Architecture

E.G.Malinovskaya, ARK Art Gallery, Almaty, Kazakhstan

The current stage of development of world culture is marked by the process of intensive formation of young national schools. of particular interest are those who came to professional creativity in the twentieth century on the basis of the mutual adaptation of cultures of various types: West - East, professional - folk, modern - folklore. Not a simple statement of the architectural chronicle, but the determination of the laws of this kind of mutual influence, given the parameters of a particular ethnocultural situation, is of paramount importance. Such a creative paradigm has not yet been the subject of research. In the process of the development of modern national schools, this concept takes on special significance in the process of studying the specifics of building new capitals of foreign countries or reconstructing existing ones, as was the case in Central Asia. An analysis of practice made it possible to identify possible options for creative models: the priority of professional or historical-cultural coordinate systems, ideally their balance. Examples of these phenomena determined the choice of article material. It characterizes the main factors of the composition of the capitals of Australia, India, Brazil and the republics of the Soviet East, revealing their mission in the dynamics of self-determination of the architecture of these countries. The main aspects of designing in synthesis with the heritage or futuristic dissonance with it by the outstanding architects Le Corbusier, 0 . Niemeyer, and architectural concepts of A.S. Kosinsky for Tashkent. A review of European and Russian avant-garde projects of the early twentieth century, transforming the Central Asian traditions of both settled and nomadic architecture, is given. Examples are studied that reflect the specifics of the work of foreign architectsprofessionals in the historical and cultural environment of the region, their role in the formation of the national identity of schools. The contribution of foreign and Soviet architects to the world heritage of modernism in the context of the tasks set by the author is indicated.

\footnotetext{
${ }^{1}$ Материал статьи связан с архитектурой модернизма. В данном номере представлен анализ по архитектуре зарубежных стран. Продолжение статьи будет посвящено специфике сложения Центральноазиатских столиц.

${ }^{2}$ Советский Восток - это республики Кавказа и Туркестана, переименованного в Среднюю Азию. С развалом СссР вновь используется историческое название региона - Центральная Азия. Термин «Советский Восток», тем не менее, употребляется, подразумевая советские республики.

${ }^{3}$ Отдельные положения статьи использовались в докладе на III Международной научно-практической конференции «Культурный текст Астаны» (к 20-летию столицы, 2018).
} 
Keywords: young national schools, new capitals, professional culture, foreign experience, traditions, innovations, West-East synthesis, Russian avant-garde projects for Central Asia, masters of modernism of the post-war decades

\section{Австралия}

Анализ событий, связанных с организацией столиц молодых национальных государств XX века представляется целесообразным начать с той страны, которая находится буквально и профессионально за горизонтом - Австралии. Особый научный интерес к ней обоснован тем, что, будучи исследователем современной архитектуры Казахстана, автор прослеживает сходные закономерности в практике этих стран, связанные со своеобразием традиционных культур, ранее относимых к отсталым, ролью инонационального влияния в процессе формирования архитектурных школ.

Немаловажно, что по сей день архитектурному сообществу постсоветских стран крайне мало известно об австралийском зодчестве, за исключением оперного театра в Сиднее (архитектор Йорн Утзон, 1959-1973). В отечественном архитектуроведении общим местом были негативные и неоправданные рассуждения о продолжительности строительства, разраставшемся бюджете (вместо 7 затратили 102 млн долларов). Критиковали образ кровли в виде серии парусообразных оболочек («ракушек»), обвиняли в самоценности и бессмысленности данного приёма. Между тем художественно-эстетические характеристики театра - приоритет образности над функцией - предвосхитили конструктивные эксперименты в неотектонической и органической стилистике сооружений архитекторов Захи Хадид, Сантьяго Калатравы, Фрая Отто, Кена Янга и других.

После длительной борьбы за реализацию своего проекта Йорн Утзон покинул Австралию. В конечном итоге он получил признание, удостоившись Притцеровской премии (2003), а сооружение справедливо внесено в список объектов Всемирного культурного наследия. Сиднейский театр очень быстро стал негласным символом государства. В силу своего уникального экспрессивного конструктивно-образного решения здание вошло в хроники минувшего столетия в качестве одного из выразительных примеров ассоциативной архитектуры 4 .

Вместе с тем, к австралийскому зодчеству начал проявляться всё больший профессиональный интерес как к особой архитектуре пятого континента: «Возможно, в скором времени архитектура Австралии будет диктовать моду и подчинять своему стилю другие страны, как в колониальный период это происходило с ней» [1]. Подробный анализ примеров «особости» не входит в нашу задачу, однако история и характер сложения австралийской столицы во многом диктуют понимание специфики архитектурного феномена страны в последние десятилетия.
Обратимся к истории. К началу XX века в Австралии сформировалась непростая общественная ситуация. Между двумя крупнейшими городами Сиднеем и Мельбурном происходила борьба за приоритет в политико-экономической жизни страны 5 . В конечном итоге в 1908 году было принято решение создать новый столичный центр, причём не на побережье, где были сосредоточены крупные города, а на материковых землях. На избранной для строительства территории сдревнейших времен проходили ритуальные обряды аборигенов и собрания австралийских вождей (Канберра переводится с языка одного из племён как «место встреч»). Представляется, что подобная духовно-насыщенная функция новой столицы - мистическое место силы - сыграла немалую роль в социокультурной консолидации нации. Процесс формирования австралийской идентичности происходил постепенно в связи со спецификой государственности, основой которой первоначально были мигранты. Важнейшим достижением социального единства выступило покаяние общества перед коренными народами: 26 мая 2008 года был учреждён праздник - День примирения. Данное событие логически закрепило духовную миссию, заложенную в основе выбора места и названия столицы.

Доминирующей составляющей, закрепившей перспективы дальнейшего роста и значимости нового города, который возник на малоосвоенных землях, стал проект генерального плана Канберры. Его авторы - американские архитекторы Уолтер Берли Гриффин и Мериан Махони Гриффин, выигравшие конкурс среди 137 его участников в мае 1912 года. Это был первый по масштабам и задачам градостроительный конкурс XX века, посвящённый строительству молодой столицы национального государства.

В тройку финалистов вошли финский архитектор и дизайнер Г.Э. Сааринен (отец) и француз А. Агаш, опытный градостроитель и социолог. Но победила чета Гриффинов. Следует отметить, что У.Б. Гриффин имел прекрасную подготовку, поработав в Чикаго с последователями «Школы прерий». Его идолом был Л.Г. Салливен, автор концепции органической архитектуры. В дальнейшем У.Б. Гриффин готовил собственные проекты в фирме Ф.Л. Райта, другого выдающегося представителя этого течения. До приезда в Австралию совместно с супругой Мериан Махони он выполнил сто тридцать проектов зданий и ландшафтов.

Приобретённый опыт четы Гриффинов послужил творческой основой для разработки проекта новой столицы Австралии. Предложенный архитекторами проект в корне отличался от принятой в стране регулярной схемы планировки городов. Концепция генплана Канберры связана с популярной в начале $\mathrm{XX}$ века идеей города-сада Э. Говарда (все финалисты отдали дань этой теории, разнясь в деталях) ${ }^{6}$. Использовав элементы проекта Л.Г. Салливена, Гриффины преодолели излишнюю «заданность» говардовской схемы - деление пространства города на отдельные сегменты по функциональному признаку

\footnotetext{
${ }^{4}$ Театральный центр Аудиторио-де-Тенерифе на Гавайях (Сантьяго Калатрава, Испания, 2003) - бесспорно творчески обыгранная, узнаваемая реплика Сиднейского театра по функциональным и образным характеристикам, что, очевидно, было авторским замыслом, знак уважения одного из выдающихся архитекторов современности своему коллеге.

${ }^{5}$ Конституция страны (1901) определила (ст. 125), что для новой столицы должен быть выделен участок земли в штате Новый Южный Уэльс общей площадью не менее 100 квадратных миль и не ближе чем в 100 милях от Сиднея.
} 
(фабричная, жилая, административная зоны). Авторы генплана Канберры отказались и от ставшей аксиомой излишней симметрии строго концентрических кругов ${ }^{7}$ (рис. 1).

Полицентричность генерального плана Гриффинов заложила перспективы к последующей динамике развития Канберры, ядра столичной агломерации с экстенсивной застройкой. Проектировщики подготовили ландшафтный вариант решения будущей столицы, исходя из реалий места - топографии участка, рельефа, природного окружения (река, покрытые лесами холмы ${ }^{8}$ ). Вместе с тем Гриффины наметили и временнь'е векторы дальнейшего роста нового города, перспективы его пространственного развития на годы вперёд. Предложенная проектом схема кольцевых и пересекающих их радиальных улиц-аллей образовала планировку существующего в наши дни центрального района (рис. 2). Основой его стали две перпендикулярные оси: заложенное в центре обширное искусственное озеро Берли-Гриффин (как дань уважения автору генплана), а также сквозная магистраль Церемониальной оси от здания парламента к Австралийскому военному мемориалу. Сохранил свою значимость, несмотря на неполную реализацию, намеченный проектировщиками «Парламентский треугольник» - логический центр столичной административной структуры.

Заложив градообразующую основу новой столицы, У.Б. Гриффин вынужден был уйти в отставку после шести лет тягот работы в условиях мировой войны и Великой депрессии,

\footnotetext{
7 Здесь и далее приводятся фотографии, находящиеся в свободном доступе в интернете.

${ }^{6}$ Данной концепции следовали планировки также и доконкурсных проектов неких «идеальных городов» при совершенно эклектичном общем стилевом решении [2]. Особую притягательность теории Э. Говарда при проектировании новых поселений придавала главная идея - город будущего. Переводчик А.Ю. Блох, общавшийся с ним в городе-саде Лечворт, данную установку даже вынес в название русской версии книги [3].
}

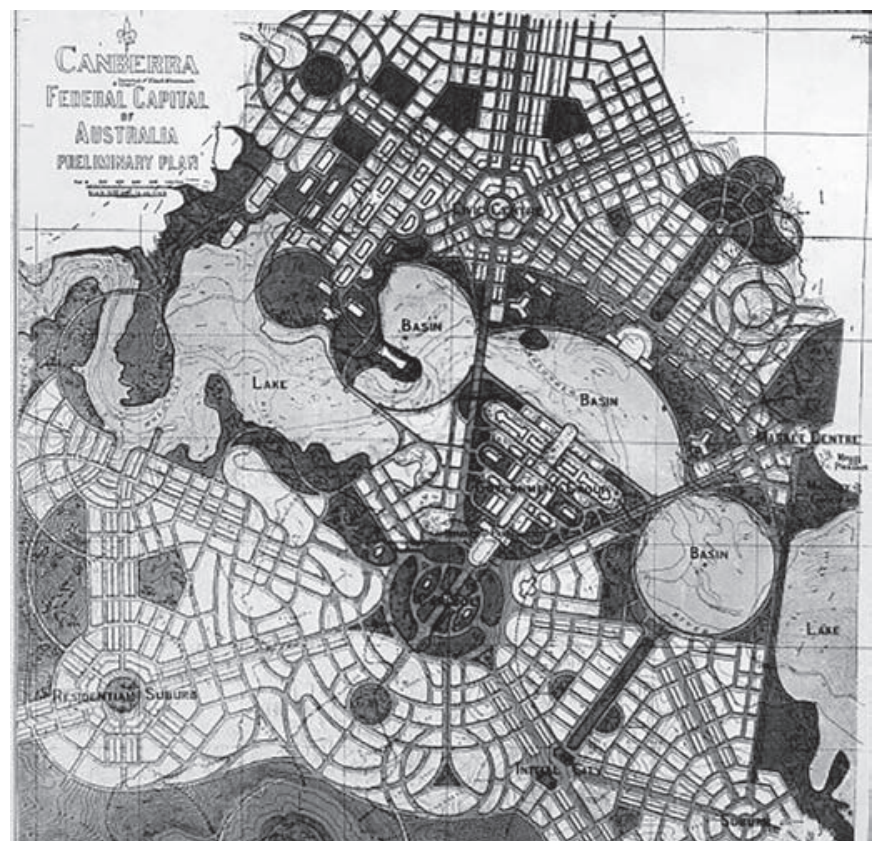

Рис. 1. Генеральный план. Канберра. Австралия. Архитекторы У.Б. Гриффин, М.М. Гриффин. 1913 год а главное - борьбы с чиновниками, обвинявшими его в «экстравагантности и нереальности проекта». Но последующее воплощение генплана, масштабно возобновлённое после Второй мировой войны, продемонстрировало, несмотря на ряд изменений, верность и рациональность первоначальной идеи 9 . Со временем оказались очевидными и другие достоинства градостроительного замысла.

Прежде всего, современная Канберра - это действительно город-сад с утопающими в зелени улицами, чья децентрализованная планировочная система в наши дни буквально спасла

${ }^{8}$ Интересно сопоставить фото панорам, сделанных с вершины Эйнсли, с выполненными вручную пометками (около 1910) и данного участка города в наши дни (2006). Очевидно топографическое соответствие основных градостроительных доминант - рельефа и последующих сооружений. См. рис. 2 а,б, любезно предоставленные автору статьи бывшим послом Австралии в России господином Питером Тэшем, выполнены с установленного на видовой площадке памятного знака во время саммита «Маунт Эйнсли» (Mount Ainslie), посвящённого юбилею проекта.

${ }^{9}$ Австралия ещё в 1980-е гг. в отношении культурного наследия стала лидирующей страной, с наибольшим размахом реализовав концепцию средового подхода - сохранение городского контекста и неприкосновенности ландшафта Канберры. В этой связи комитет «Наследие Гриффинов» не только занимается популяризацией их творчества, но поставил вопрос о возможности реконструкции проекта в полном объёме.

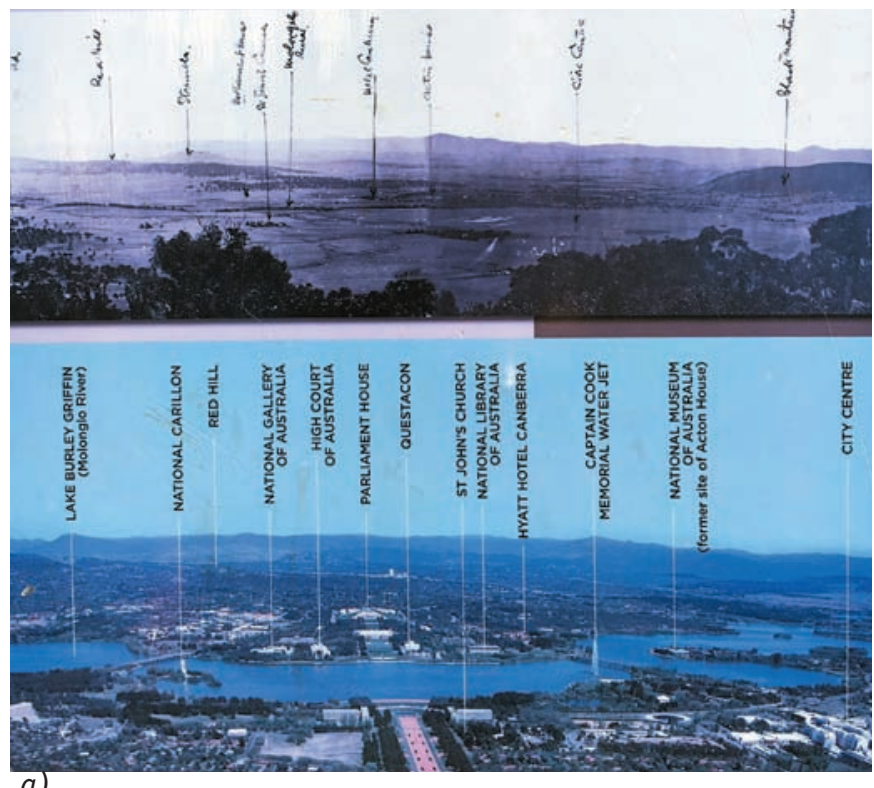

a)

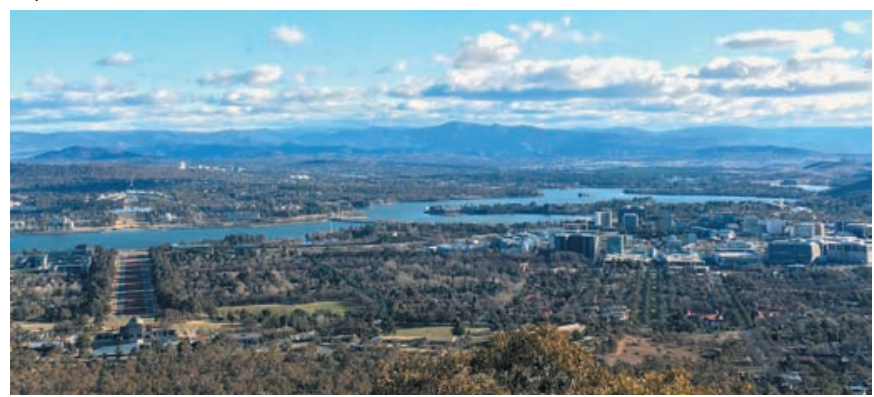

б)

Puс. 2. Фото панорамы участка, выбранного для столицы: а) около 1910 года; б) современная застройка. 2006 год 
его от транспортной нагрузки. Канберра, в отличие от многих столиц мира, не перенаселена - около 400000 жителей. К удаче проекта следует отнести то, что городское пространство плавно перетекает в окружающие ландшафты. Всё это, помимо ощущения единства и комфорта городской среды, формирует восприятие её цельности также и с ближайшими поселениями. Небольшие города-спутники в предместьях (Уэстон Крик, Белконен, Тагерранонг, Гангалин), имея сходную с Канберрой планировочную модель, связаны со столицей артериями дорог, перемежающихся с озеленёнными участками, что контрастирует с большинством современных городов (и не только в Австралии), бессистемно расползающихся по мере их роста.

Проектировщики, заложившие основы первых поселений, городов континента в планировке и в облике сооружений, придерживались европейской и американской строительных традиций. Использование профессиональной культурой исключительно инонациональных образцов было присуще и архитектуре Канберры. В связи с мировой политической ситуацией - две мировые войны и последующие кризисы город вплоть до 1960-х годов развивался крайне медленно. Австралийская архитектура тех лет вошла в эпоху модернизма, тенденции которого проявили себя первоначально достаточно робко, вплоть до откровенных подражаний находкам мастеров этого направления. В частности, самонесущая конструкция трёхуровневого здания Академии наук («Купол Шайна», архитектор Рой Граундс, 1959; d=45,74 м) - очевидная реплика знаменитого купола итальянца П.Л. Нерви (рис. 3). Со временем архитекторы начали работать творчески более гибко, обнаруживая только стилевую принадлежность к различным направлениям мировой архитектуры, но без прямых цитат. Использовались те или иные приёмы функционализма, структурализма, деконструктивизма, брутализма (Национальная галерея, архитектор Колин Мэдиган, 1997-2001) (рис. 4).

Все это постепенно сформировало профессиональную базу современной архитектуры Австралии. Как результат - нестандартные, яркие постмодернистские эксперименты начала XXI века, даже откровенно футуристические: от особняков - до крупных объектов. И не только в столице. В приморской деревушке Блэргаури на побережье построен небольшой, с асимметричными фасадами деревянный дом, столь образно оригинальный, что критики сочли возможным сравнить его с орга́ном (Letter Box House, Макбрайд Чарльз Райан, 2009) (рис. 5). Такого рода творческие находки побуждают не к поискам аналогов в мировой практике - инонациональных заимствований, - но и дают основание констатировать зрелость национальной школы, проявляющей творческую и стилевую независимость.

Постмодернистским примером может служить талантливое решение серии сооружений в Канберре для Национального университета Австралии (АНУ) по проекту дизайн-студии «Лайонс Аркитектс» (Lyons Architects). Шестигранный объём здания «Хедли Булл» (2008) по фасадам обработан мощными бетонными панелями с горизонтальными линзами близкого к ромбу, сложного по рисунку и фактуре солнцезащиты-осте-

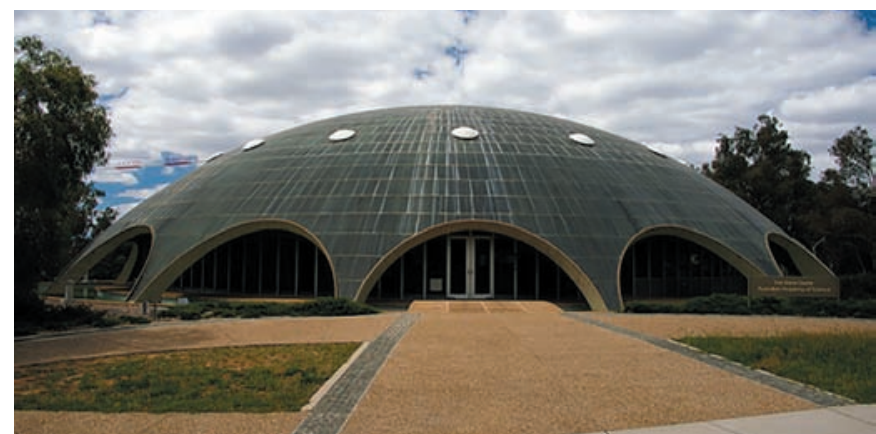

Рис. 3. «Купол Шайна». Канберра, Австралия. Архитектор Рой Граундс. 1959 год

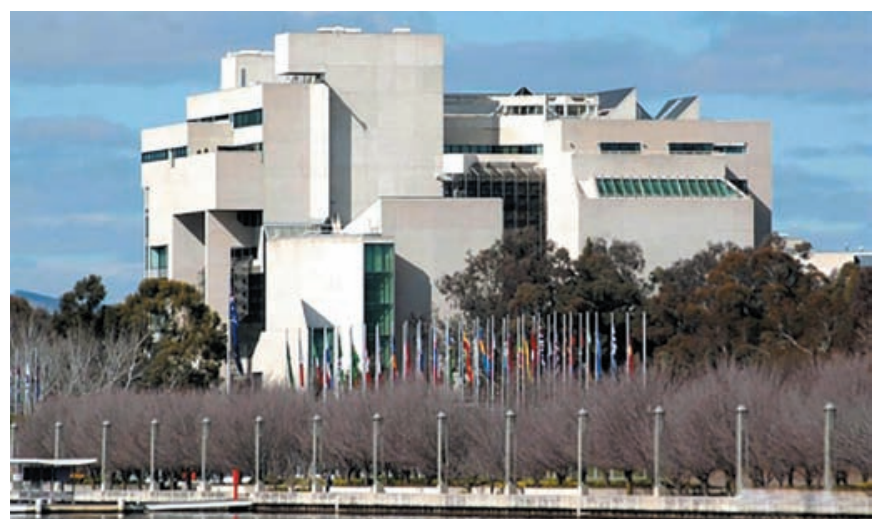

Рис. 4. Национальная галерея. Канберра, Австралия. Архитектор Колин Мэдиган. 1997-2001 годы

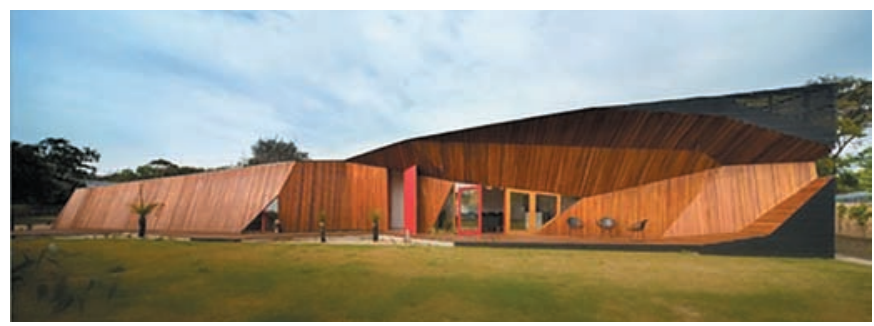

a)
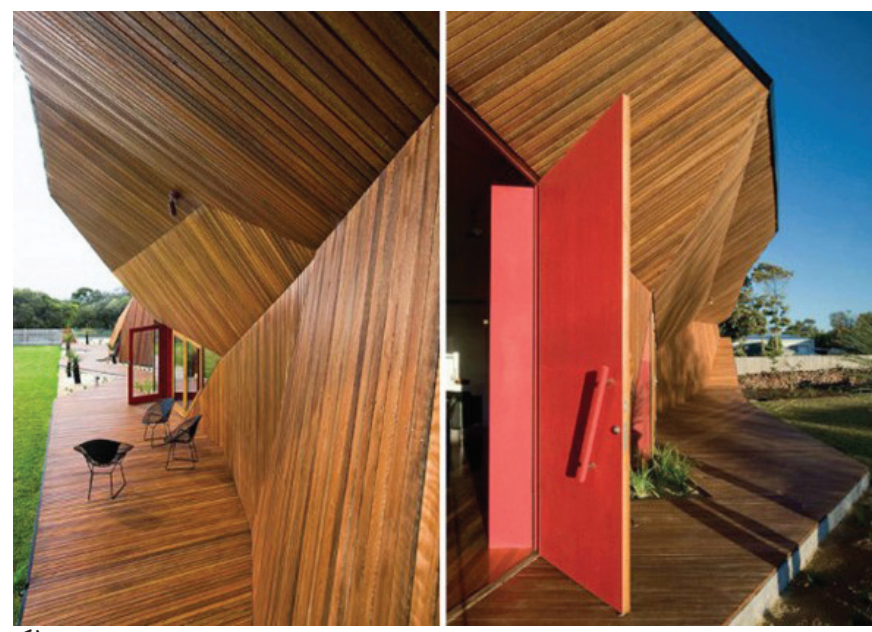

б)

Puc. 5. Дом на побережье (Letter Box House). Блэргаури, Австралия. Макбрайд Чарльз Райан. 2009 год: а) общий вид; б) перспектива ракурса на стыке фасадов 
кления. Внутренняя структура имеет обширный атриум-форум на всю высоту здания - конструктивно и функционально обыгранное пространство, независимое от факторов влияния улицы и климата (рис. 6). Не менее визуально-символична трактовка Медицинского исследовательского центра (John Curtin school, 2011), экспрессивный по форме объём которого складывается из системы смежных зеркальных окон-солнцезащит. Они формируют некое подобие волнореза со сложным абрисом фасада и кровли. Концепция образа, построенного с помощью выступов, по мысли авторов, выражает этапы роста знаний в медицине (рис. 7).

Однако, с точки зрения художественно-стилистического анализа, как в данном сооружении, так и в ряде других построек присутствуют в определённой мере ассоциации с Сиднейским театром или же чем-то морским: парусом, волной, кораблём (рис. 8). Подобные явления обнаруживают качественно важный аспект архитектурной практики - наличие современных профессионально-творческих моделей. Они бесспорно ощущаются

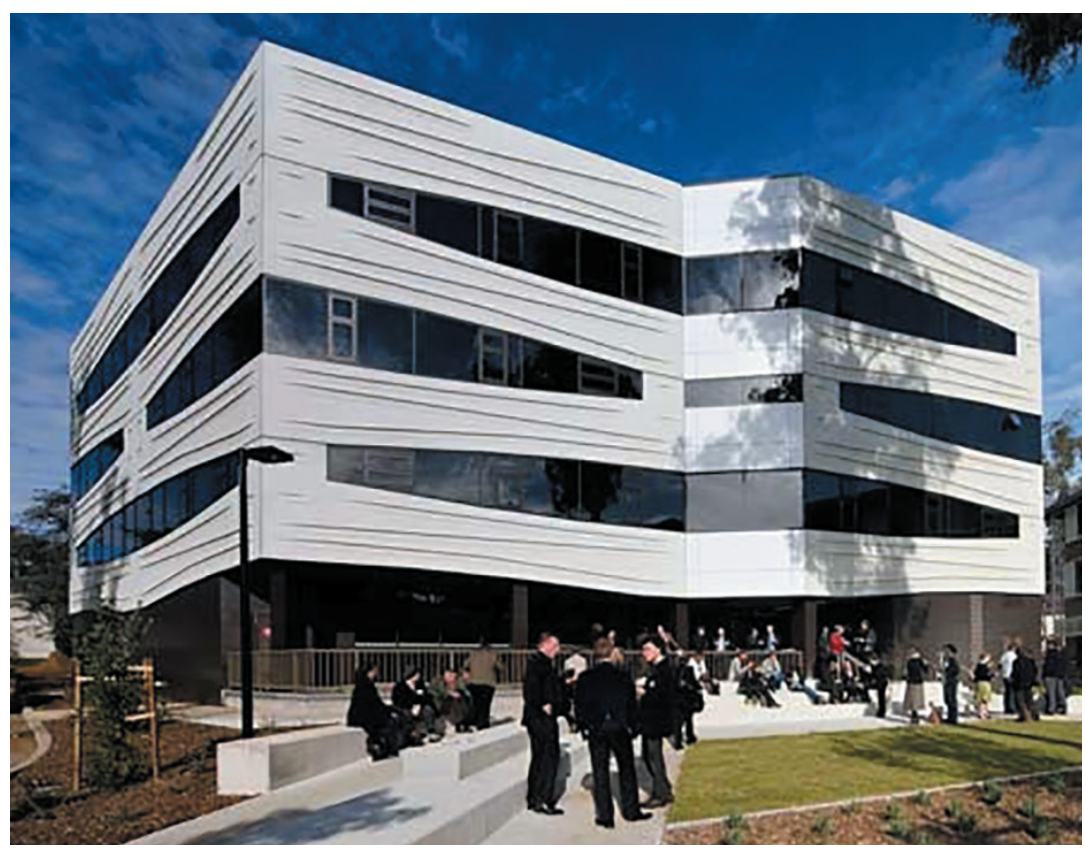

a)

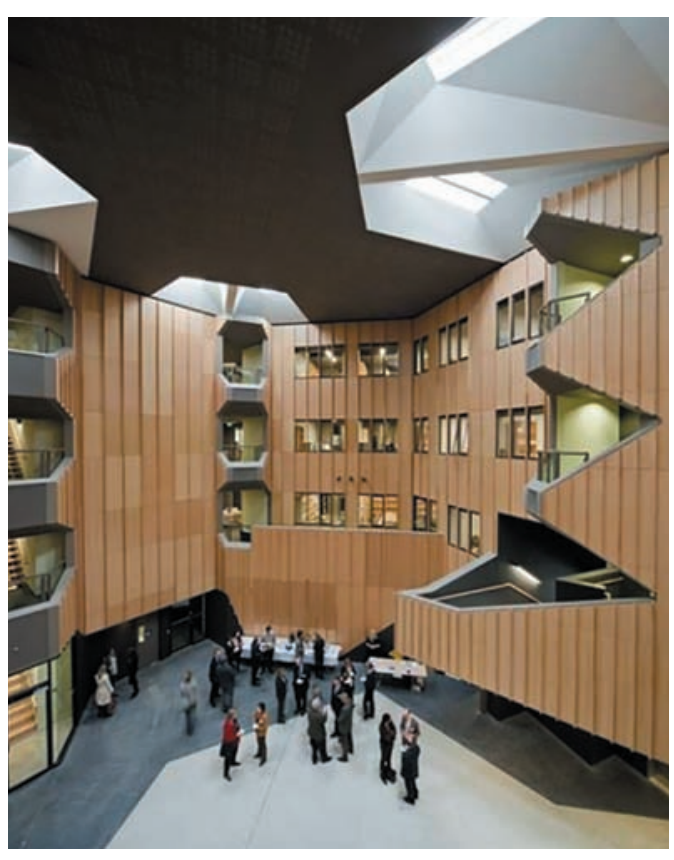

б)

Puс. 6. «Хедли Булл». Канберра, Австралия. Дизайн-студия «Лайонс Аркитектс» (Lyons Architects). 2008 год: а) перспектива; б) атриум

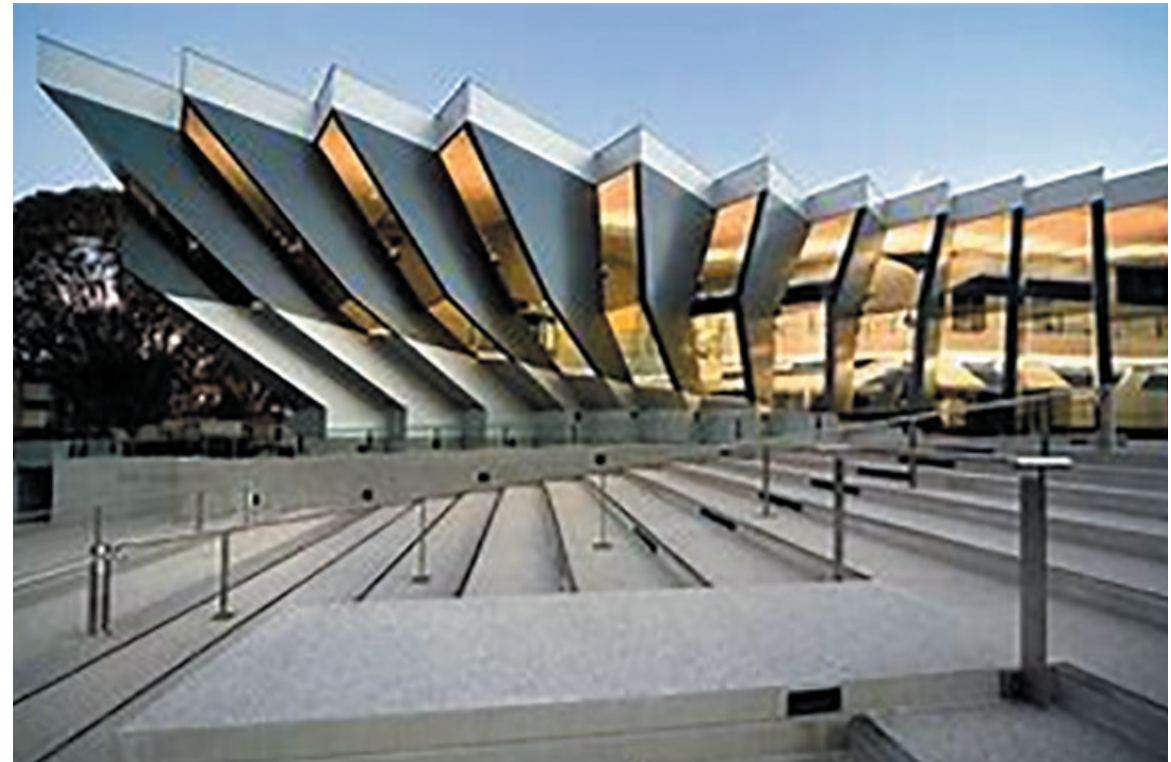

Pис. 7. Медицинский исследовательский центр «Джон Кёртин скул»(John Curtin school), Канберра, Австралия. Дизайн студия «Лайонс Аркитектс» (Lyons Architects). 2011200

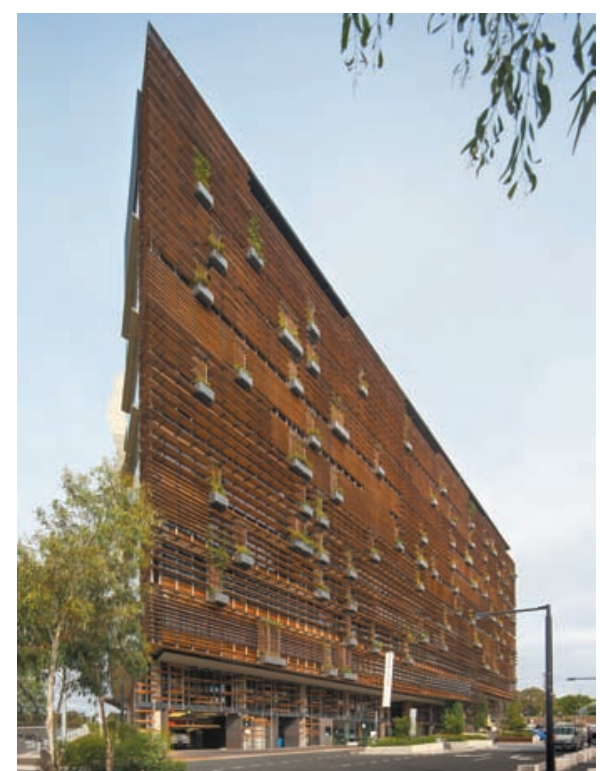

Puc. 8. Гостиница «Оволо Ниши» (Ovolo Nishi). Канберра, Австралия. Архитектурное агентство «Фендер Катсалидис Острэйлиа». Мельбурн. (Fender Katsalidis Australia. Melbourne). 2015 год 
авторами, формируя диапазон отсылок на знаковые объекты предшествующих этапов развития австралийской архитектуры - собственной национальной традиции. То есть, как отмечалось, вне подражания международным образцам, что имело место в начальный период становления архитектурной школы страны.

Стартовав с нуля, современная архитектура Австралии, профессиональные основы которой лежат в контексте мирового зодчества XX века, демонстрирует пример самобытности, хотя и автономной по отношению к сложной для освоения культуре коренных народов континента. Специфика традиций коренных народов Австралии длительное время ощущалась не более чем первобытная. Издержки колониальной политики долгое время не вызывали к этому наследию никакого интереса.

Пожалуй, в данном контексте представляет интерес здание Национального музея (арх. Ховард Рэггат, 1997-2001) (рис. 9). Вызывающая у многих недоумение архитектура, которую
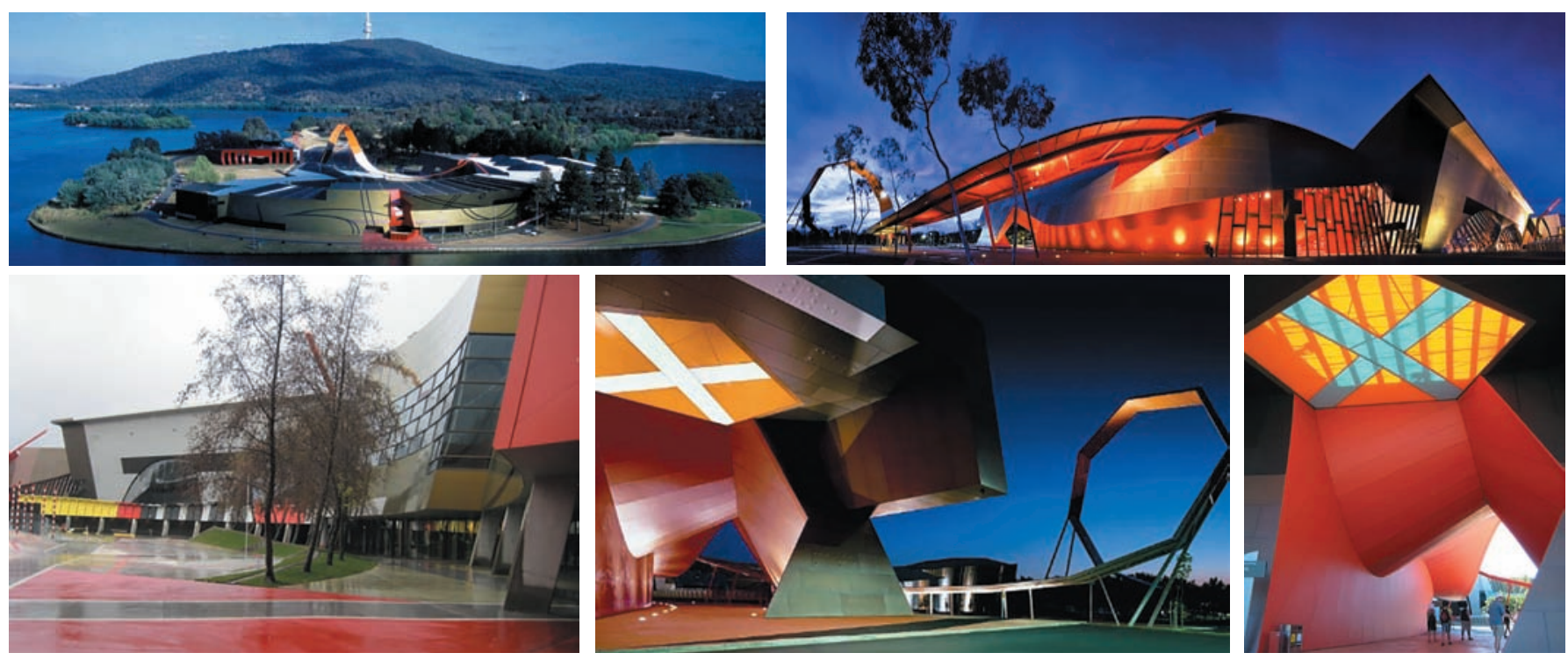

Рис. 9. Национальный музей. Канберра, Австралия. Архитектор Ховард Рэггат. 1997-2001 годы

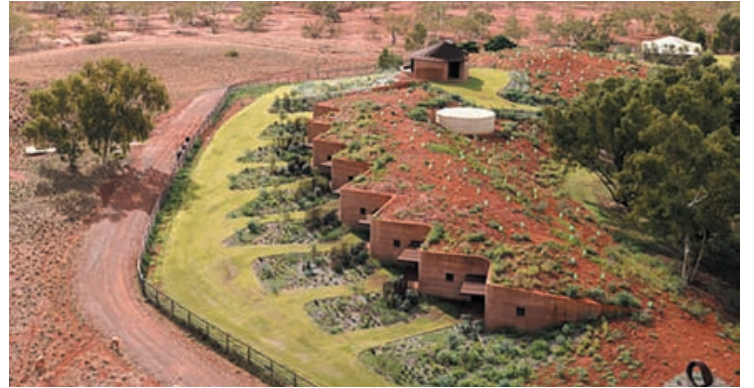

a)

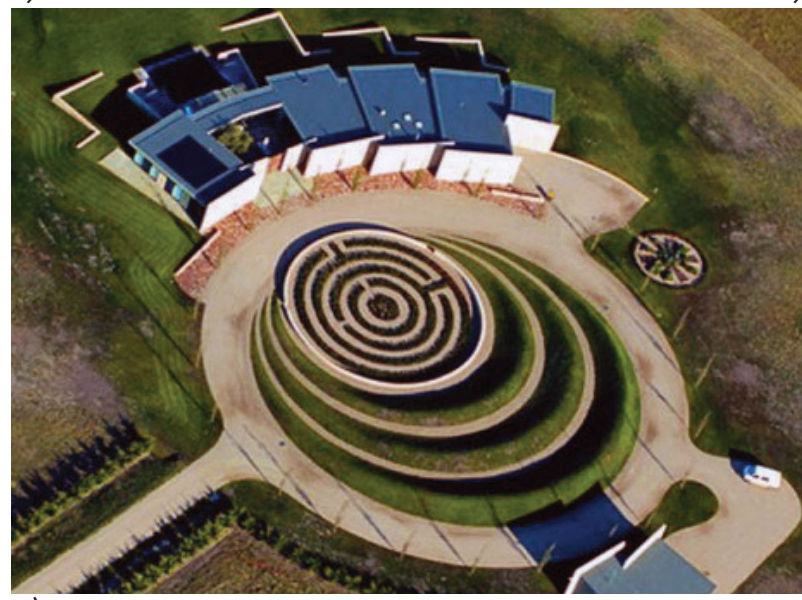

B)

б)
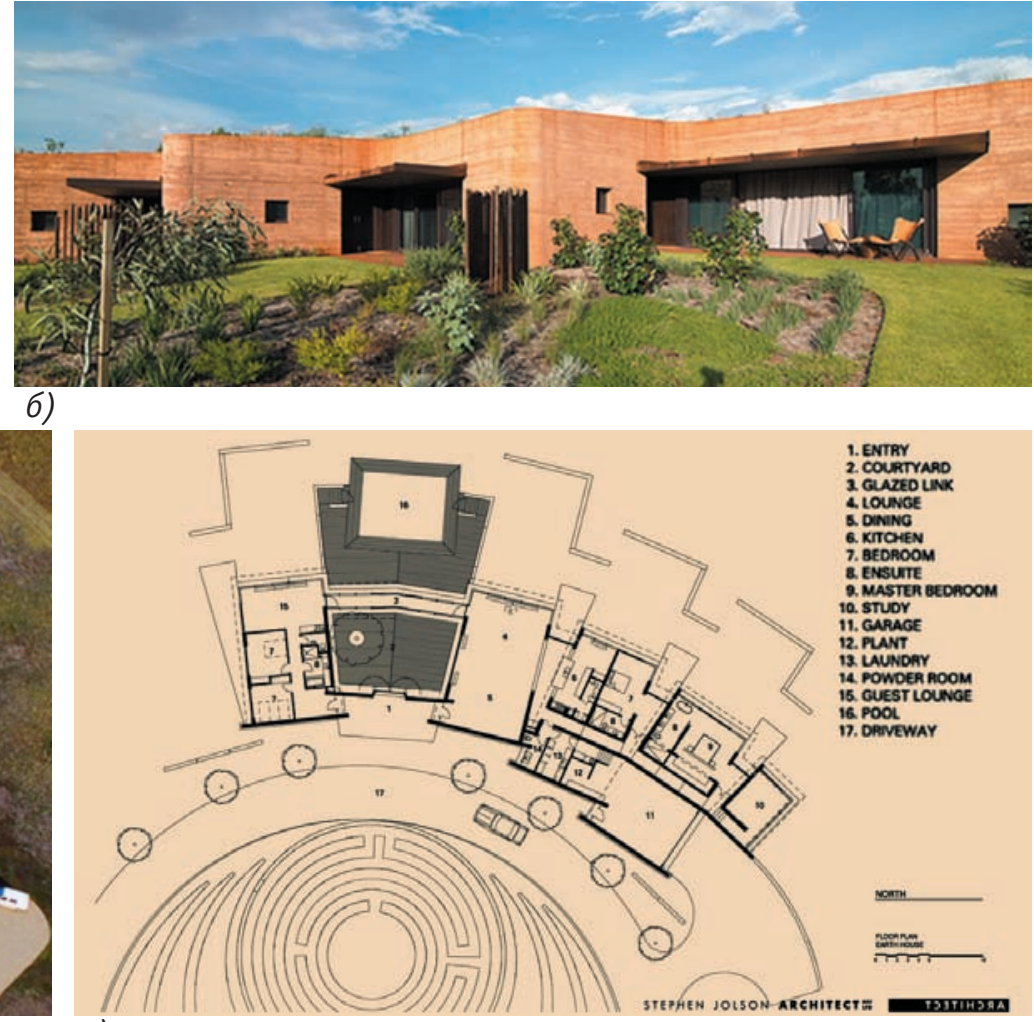

2)

Рис. 10. Комплекс резиденций «Земляная стена»: а) панорама; б) фрагмент фронтальной стены. Западная Австралия. Архитектор Луиджи Россели. 2017 год. «Земляной дом» (Earth House): в) перспектива; г) генплан. Штат Виктория. Австралия. Архитектурное агентство «Джолсон Аркитекче Интериорс» (Jolson Architecture Interiors). 2010 год. 
критики определяют как постмодернистскую, против чего трудно возразить, учитывая систему приёмов и «язык» данного направления, лично для меня создаёт очевидную визуальную «транскрипцию» закреплённого на опоры полога первобытного жилища аборигенов. Подобную символику активизирует и подкрепляет асимметрия ярких цветовых пятен, деталей и элементов решения фасадов. Современные конструктивнопластические возможности обыграны смело и убедительно также и в интерьере, как самостоятельной пространственноструктурной единице, независимой от экстерьера. Был задан выразительный стилевой вектор, сходный с принципом решения атриума здания «Хедли Булл».

Примером поиска своеобразия австралийской архитектуры, исходя из параметров и требований «места» ${ }^{10}$ - климатических и исторических, - могут служить проекты всё более популярного в разных странах направления экологической архитектуры [5]. Подразумеваем опыт популярной в последние годы «земляной архитектуры», где источником идей стали принципы устройства первобытных построек, трансформированных в остросовременные и комфортные сооружения. Объекты находятся вне столицы, но их нельзя не упомянуть в связи с интересом проектировщиков к традициям коренных народов, что даёт основание говорить о качественно иных задачах профессиональной школы. Решение «Земляного дома» (2010, 465 кв.м), по мнению авторов, стирает грань между архитектурой, природой и дизайном интерьеров. Выполненное из утрамбованного местного грунта здание, словно вырастая из земли, органично вошло в прибрежный ландшафт. Так называемая «Земляная стена» (2017, длиной 210 м) - пример использования приёмов естественного охлаждения в проекте Луиджи Россели, финалиста архитектурного конкурса в Западной Австралии [6]. Крышей и задней стеной комплекса из двенадцати резиденций для временного пребывания на ферме служит природная дюна, защищающая от нагрева в субтропическом климате ${ }^{11}$ (рис. 10).

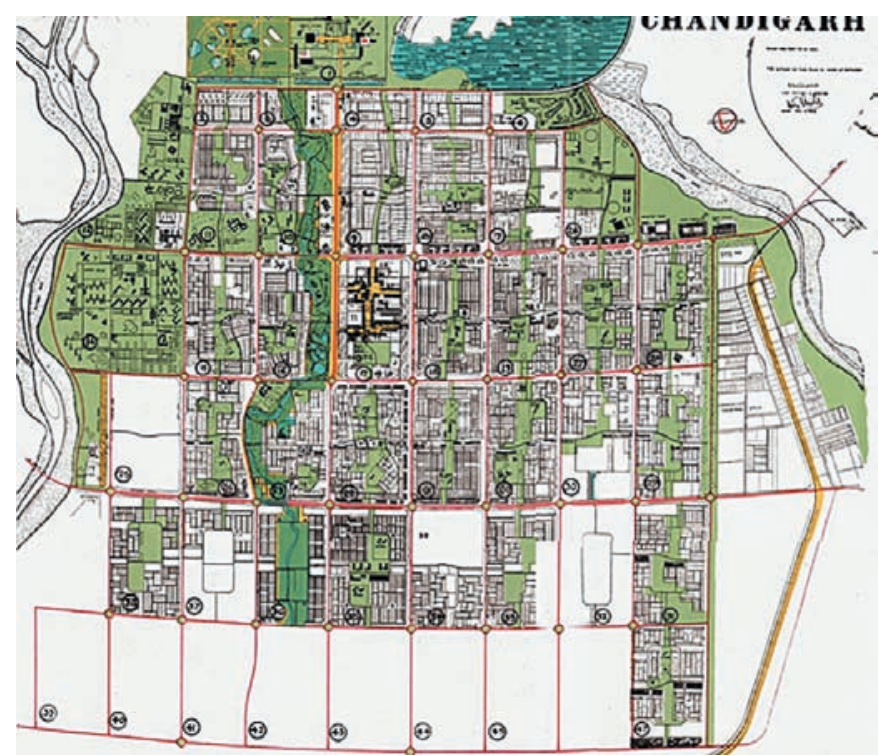

Рис. 11. Генеральный план города. Чандигарх, Индия. Архитектор Ле Корбюзье. 1952-1955 годы
Специфика такого рода сооружений позволяет индивидуализировать установки проектной работы, реализовав гуманистическую концепцию советских архитекторов-дезурбанистов 1920-х годов о жилище, как проявлении человеческой личности. В наши дни подобные творческие задачи становятся всё более актуальными. В частности, их формулируют программа и проектные предложения международного конкурса «Лака: архитектура, которая реагирует» (Польша). Идея конкурса связана с попыткой отказа от современных профессиональных стереотипов - образных, конструктивных, выбора материалов: «найти архитектурные, технологические решения, способные динамично взаимодействовать с окружающей средой» [8]. И, добавим, обратиться не к наработкам профессиональной архитектуры (технологиям, сложившейся системе видов, стилей, жанров), а к народной культуре. Что важно - даже географически далёких народов. Например, модернизированная или подлинная юрта кочевника используется во многих странах вплоть до Скандинавии. Подобные решения служат не альтернативой другим направлениям творческой практики, но одним из её вариантов, знаменуя развенчание преимуществ европоцентризма - образа жизни и мысли ${ }^{12}$.

В послевоенный период также на пустом месте и в кардинально короткие сроки возникли города Бразилиа и Чандигарх. Стимулом к их появлению стал замысел руководителей национальных государств языком современной архитектуры выразить новый социокультурный этап развития этих стран. Архитектура новых столиц должна была олицетворять общественные перемены символико-ассоциативными рядами творческих приёмов и находок.

\section{Индия, Чандигарх}

По предложениюД. Нерудемократические идеи независимости Индии в архитектуре города Чандигарха, столицы союзной территории, воплотил известный французский архитектор Ле Корбюзье (при участии П. Жаннере, 1951-1956) [10]. Генеральный план архитектор задумал как развивающийся организм. Чтобы ликвидировать тенденцию к неконтролируемому разрастанию города, Ле Корбюзье предложил сделать по периметру его территории зелёную

10 Здесь и далее автор цитирует, закавычив, терминологический ряд (не концепцию) А.С. Косинского, удачно отражающий параметры деятельности проектировщиков: «место» - апеллирование к традициям, «время» - установки архитектора-профессионала [4].

${ }^{11}$ Комплекс напоминает приёмы преодоления агрессивного климата в подземных сооружениях города Кубер Педи, штата Южная Австралия, с населением около 2000 жителей. Построенные между шахтами, где вели добычу опалов, здания не только спасают от жара пустыни, но и сохраняют неизменную температуру в течение года - около $+23^{\circ} \mathrm{C}$. Сложные в плане, многоуровневые помещения, сделанные в выработках грунта, имеют перспективу свободного разрастания вглубь по мере необходимости. Основанный в начале XX века город включает основные типы зданий (жилье, кафе, гаражи, магазины, винные погреба, склады), а также просторный храм со скальными рельефами на темы христианской мифологии [7].

12 Интерес к подобным приёмам строительства возникал в среде профессиональных архитекторов периодически в течение всего XX века, о чём автор неоднократно писала, начиная с кандидатской диссертации [9]. Подробнее см. во второй части статьи. 
зону шириной 16 км. Вместе с озером это стало важным фактором улучшения микроклимата засушливой равнины.

Город Чандигарх, расположенный в зелени рощ между двух рек и рукотворным озером, с прямоугольной схемой кварталов, состоит из 47-ми секторов размером 800×1200 м (рис. 11). Архитектор спланировал их самостоятельными, индивидуально решёнными градообразующими единицами с учебными и торговыми зданиями в шаговой доступности от жилья. Транспортная система тщательно продумана: органично связывает в единую сеть участки озеленения и магистрали, проспекты, межквартальные и пешеходные улочки в жилых секторах [11, с. 169-176].

Помимо градостроительных задач Ле Корбюзье взял на себя проектирование ансамбля наиболее значимых общественно-административных зданий, вынесенных за пределы новой столицы: Дворца Юстиции, Ассамблеи (Парламента) (рис. 12), Музея и Художественной Галереи, а также Секре- тариата, входившего в комплекс Капитолия. Один из «отцов-основателей» модернизма, в сооружениях Чандигарха архитектор обнаружил произошедшие в его творчестве перемены. Используя технику необработанного бетона в цветовых и пластических элементах сооружений (при приоритете краснокирпичной кладки), Ле Корбюзье реализовал приверженность к новому для архитектуры тех лет явлению - брутализму. Скульптуре придавался характер малой архитектурной формы - вращающийся монумент «0ткрытая рука» на Братской могиле ( $\mathrm{h}=26$ м), символизируя гуманистическую идею «Готов отдать, готов принять» $[11$, с. 132, 180]. В свою очередь, практически скульптурно решён выразительный по планировке трилистник музея Махатмы Ганди «Ганди Бхаван» (архитектор Б.П. Махур, 1955) (рис. 13, 14).

Вместе с тем понимание актуальности обращения к культуре страны, что было новым для него, модерниста, подтолкнуло Ле Корбюзье к приёмам решения среды не только через особен-

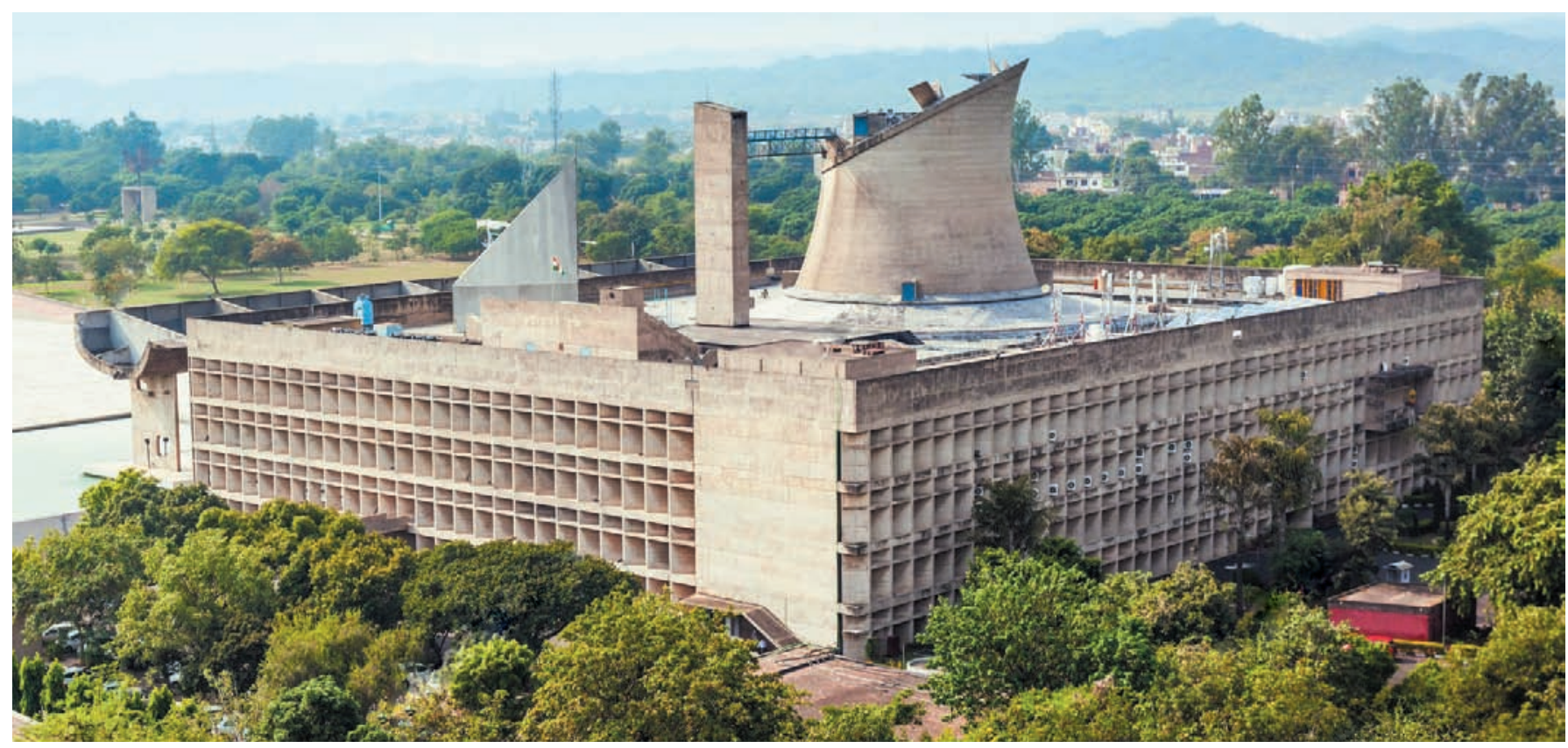

Рис. 12. Дворец Ассамблеи. Панорама. Комплекс Капитолия. Чандигарх, Индия. Архитектор Ле Корбюзье. 1952-1956 годы

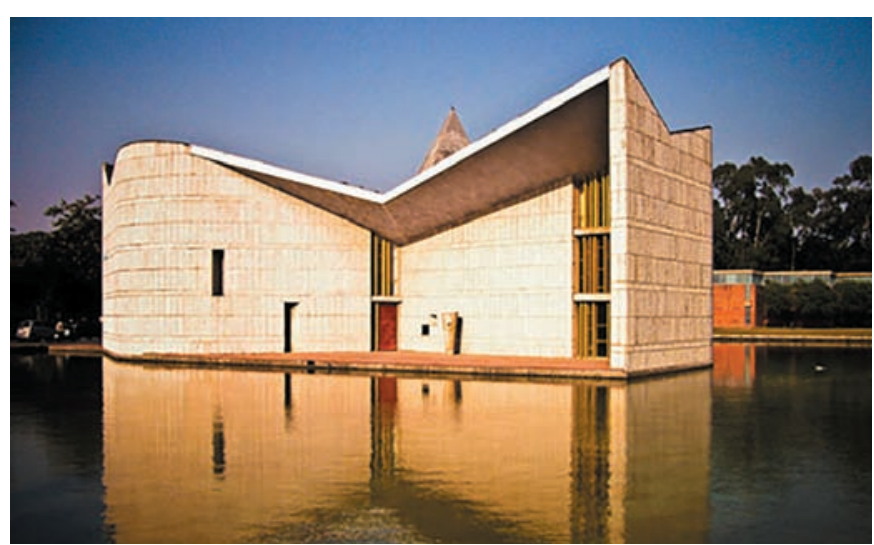

Рис. 13. Мемориальный музей Махатмы Ганди («Ганди Бхаван»). Чандигарх, Индия. Архитектор Б.П. Махур. 1955 год

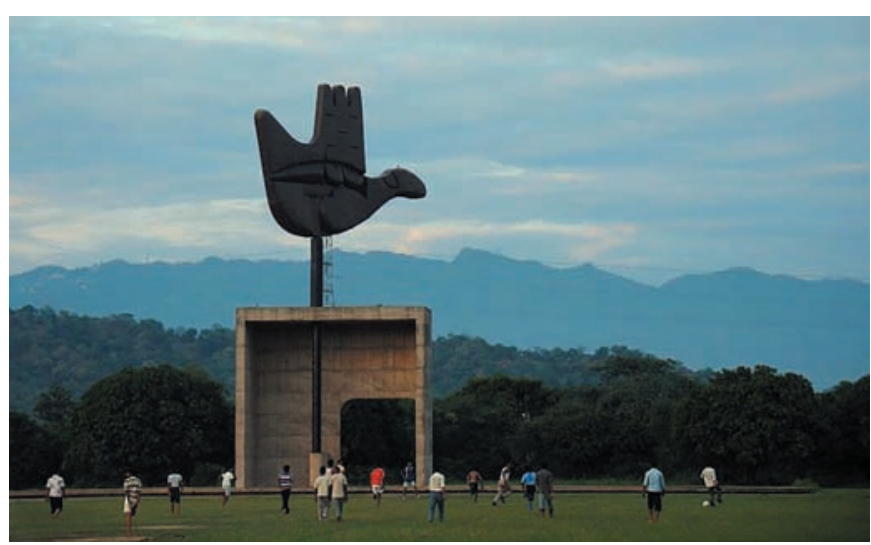

Рис. 14. Монумент «Открытая рука» на Братской могиле. Комплекс Капитолия. Чандигарх, Индия. Архитектор Ле Корбюзье. 1965 год 
ности ландшафта. Создав концептуально-единый контекст города, проектировщик ответил и на вызовы «места», чему способствовало сотворчество с индийскими партнёрамиархитекторами, получившими образование в Европе и США. В дальнейшем это имело большое значение для развития молодой национальной школы и заложило основу целого направления последователей Ле Корбюзье. В прямоугольной решётке градостроительной схемы использовались различные по ширине улицы в зависимости от функции, как принято в Индии: магистральные, узкие межквартальные, пешеходные,

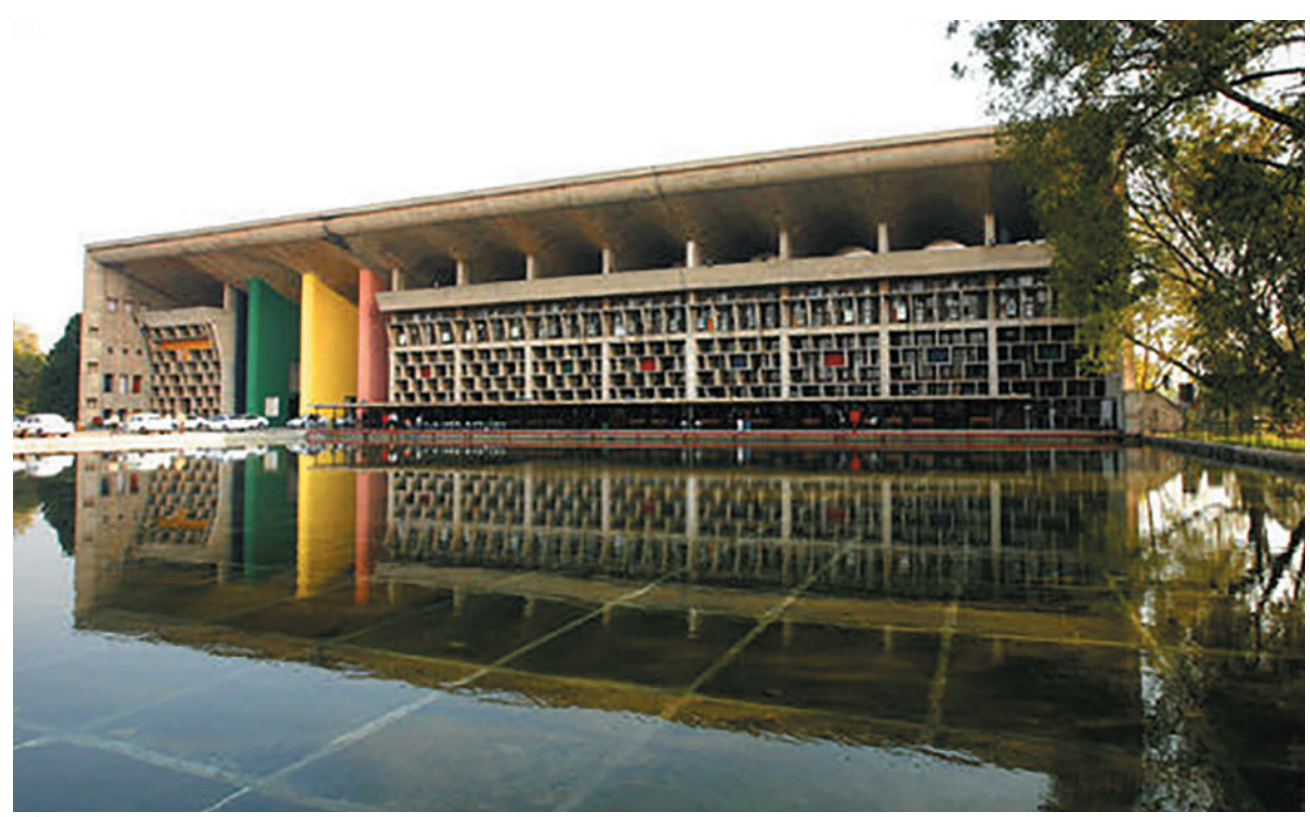

a)

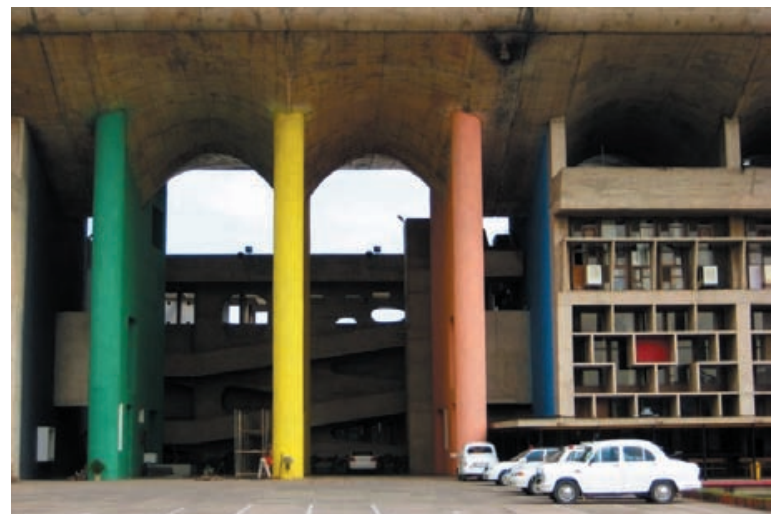

B)

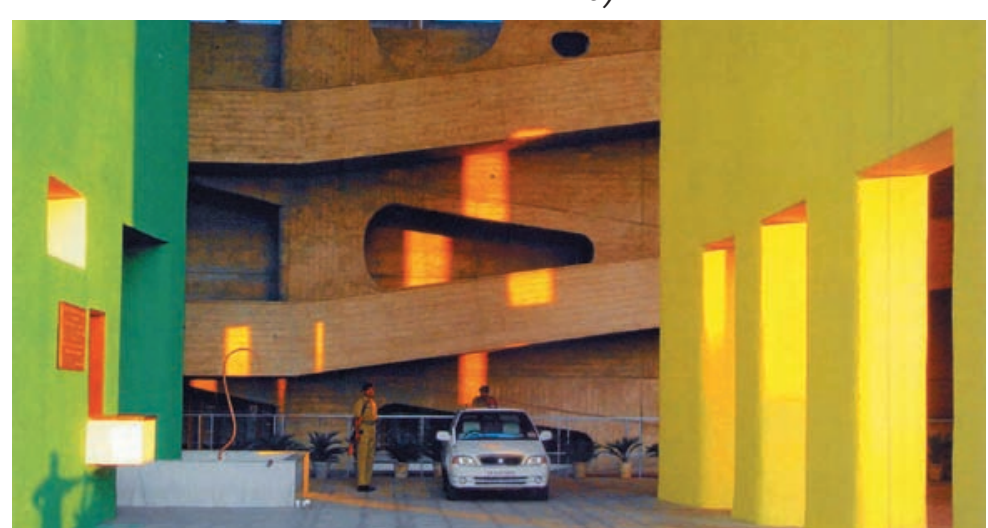

2)

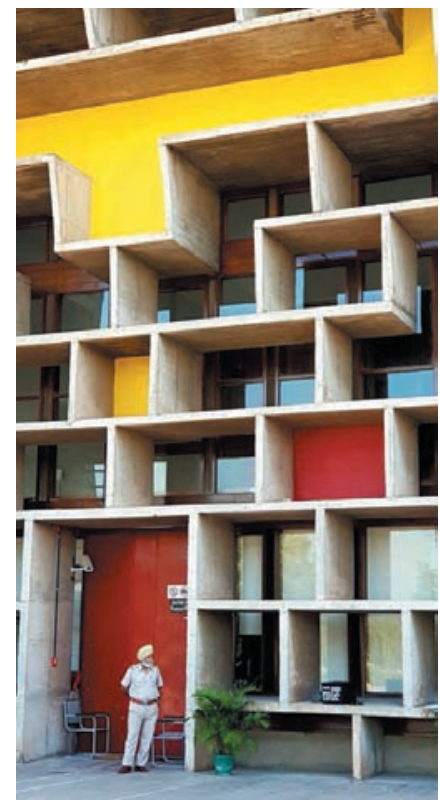

б)

Рис. 15. Дворец Юстиции. Чандигарх, Индия. Архитектор Ле Корбюзье. 1951-1955 годы: а) панорама;

б) стена-солнцезащита; в) пилоны портика; г) пандусы портика
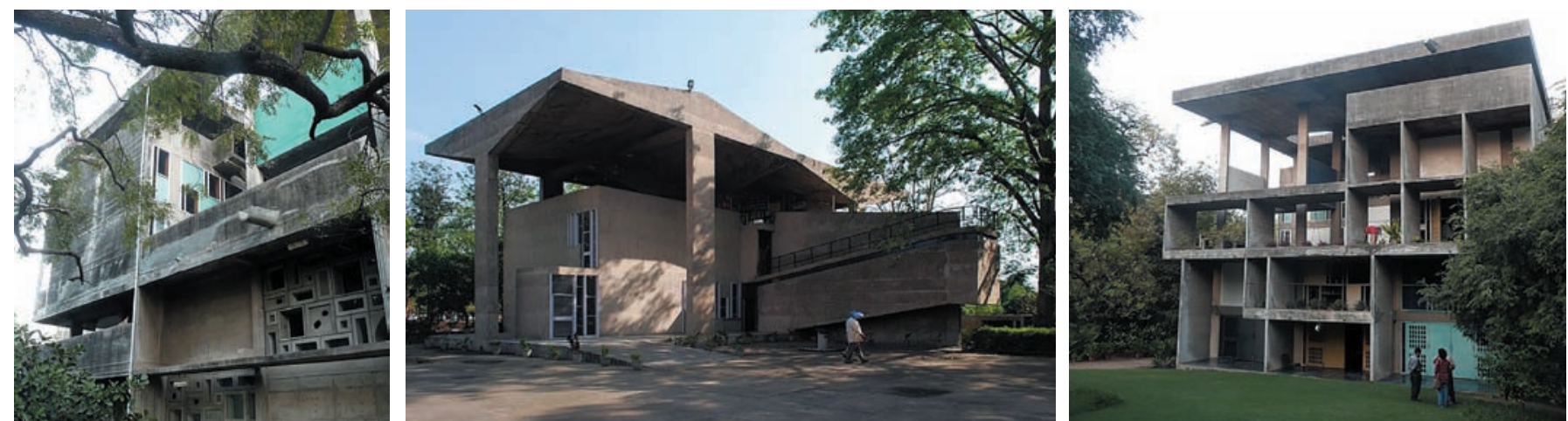

Pис. 16. Жилые дома для одной семьи. Чандигарх, Индия. 1954-1960 годы 


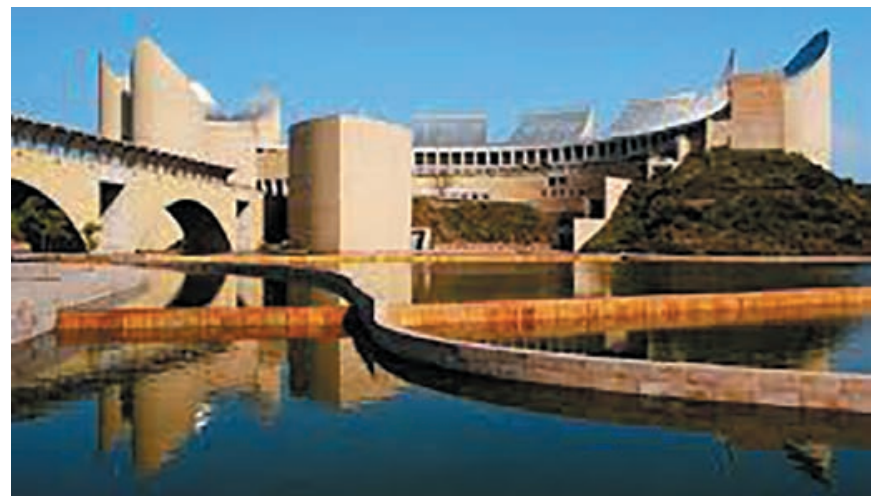

a)

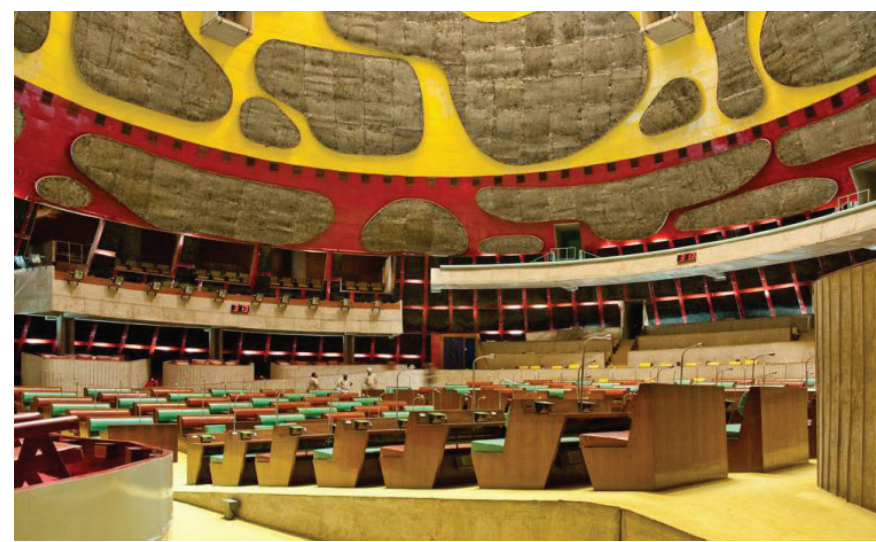

б)

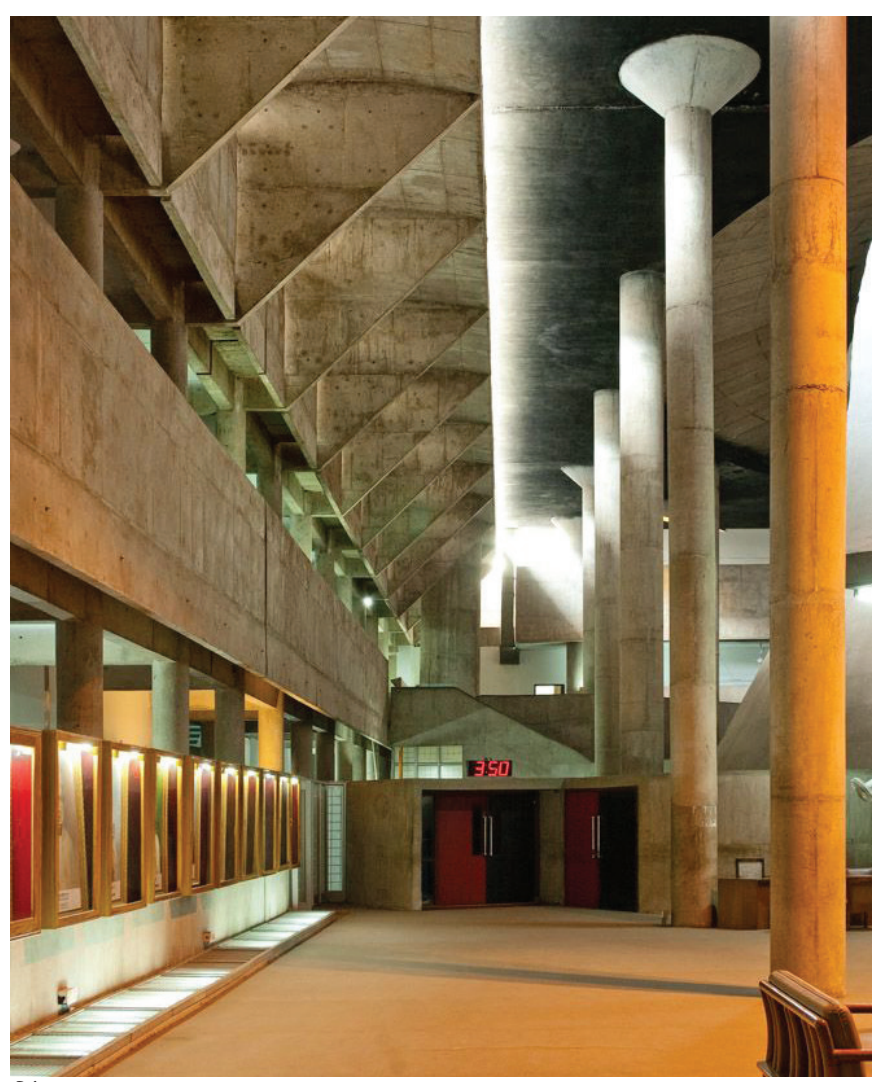

Ә)

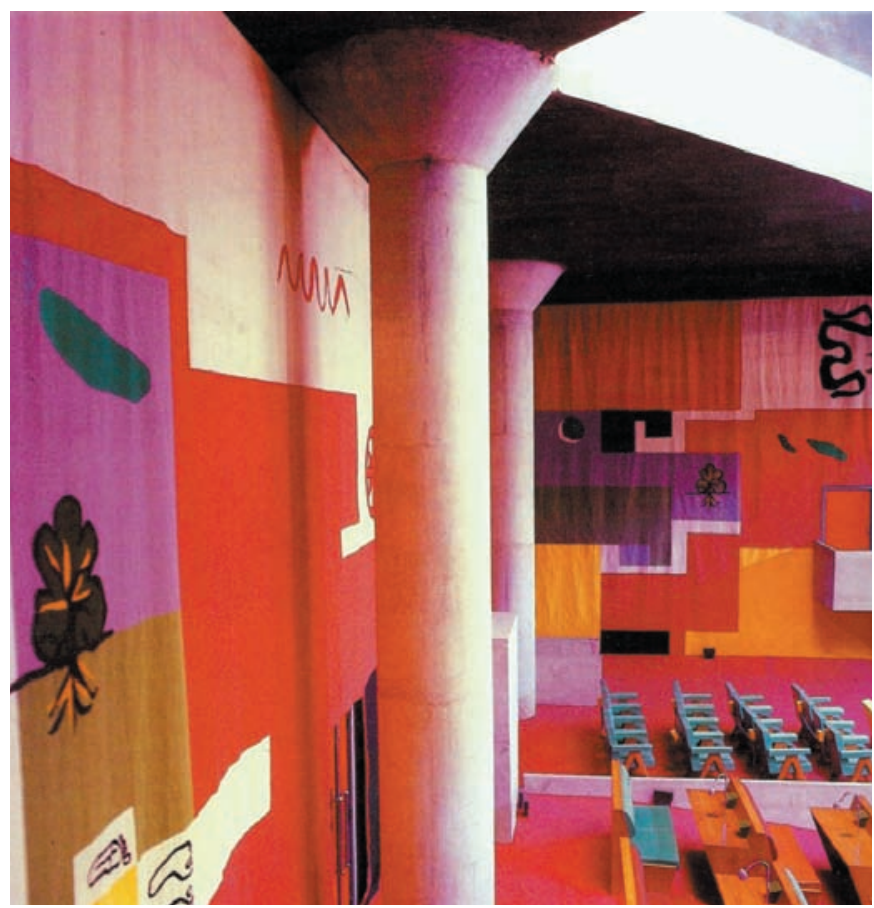

B)

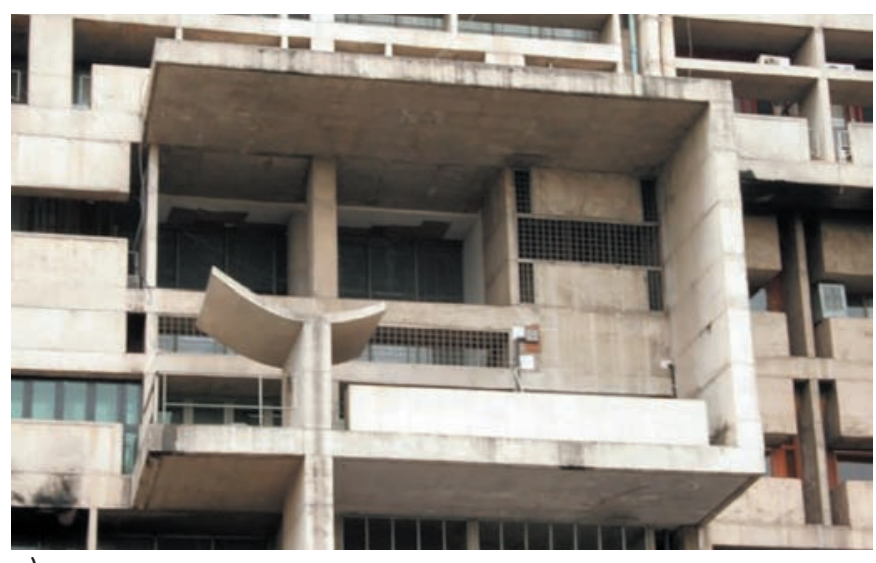

2)

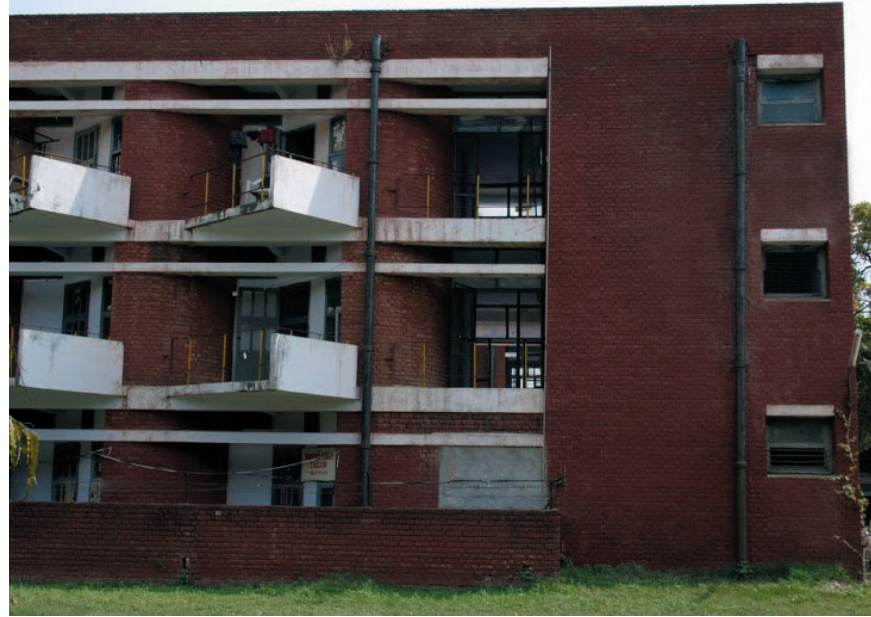

e)

Рис. 17. Цвет и пластика деталей. Дворец Ассамблеи. Комплекс Капитолия. Чандигарх, Индия. Архитектор Ле Корбюзье. 1952-1956 годы: а) общий вид; б) интерьер зала заседаний; в) громадные гобелены в декоре одного из залов (эскизы по рисункам Ле Корбюзье, ткачество кашмирскихмастеров); д) входная группа; г, е) балконы, лоджии-солнцезащитные и цвето-пластические элементы фасадов 
транспортные (исторический прообраз - караванные). Заменив привычные для европейцев крупные торговые магазины «базарными улицами», которые на Востоке служат не только для торговли, но и общения, авторы усилили их роль объектами современного социально-культурного центра района с клубом, библиотекой, рестораном, больницей, кинотеатром. Повсеместно нашли применение средства климатической адаптации: лужайки, бассейны, замкнутые дворы с озеленением.

Кроме средообразования, местные традиции нашли применение при проектировании жилых кварталов, в чём опыт индийских проектировщиков был решающим (рис. 16). Пластика и отдельные конструктивно-образные элементы ассоциируются с деталями народной архитектуры: использование гальки для отделки, различные по размерам небольшие окна на фоне «глухих», с асимметричными деталями фасадов. Объёмы лестниц ведут с земли на верхний уровень, плоские кровли служат продолжением интерьера, как летняя спальня или мини-сад. Нижние уровни зданий затеняются сквозными террасами, которые защищают фасады от солнца и обеспечивают горизонтальную аэрацию.

Что важно, эта практика привела Ле Корбюзье к осознанию перспектив использования традиционной культуры и в крупных объектах города. Следуя рационалистским установкам архитектуры XX века, то есть, «времени», Ле Корбюзье здраво оценил функциональные параметры исторического зодчества Индии, созвучные приёмам модернизма. Например, игра объёмами, смена их уровней с опорой на простые, круглые в сечении столбы (излюбленный приём мастера задолго до этого). Нашли применение цветовые акценты в экстерьерах и внутри зданий, игра света в заглублённых оконных проёмах и в орнаментальных структурах фасадов (рис. 17 а, б, в, д). Индийские мелкие оконные решётки «джали», трансформированные в крупные объёмы, приобрели конструктивно-функциональную роль. Идея стен-солнцерезов, со спрятанными в их торцах балконами прочно вошла в «словарь» современной архитектуры (рис. 17 г, д).

a)

Рис. 18. Город Бразилиа: а) генеральный план. Архитектор Лючиа Коста. 1957 год; б) панорама центра

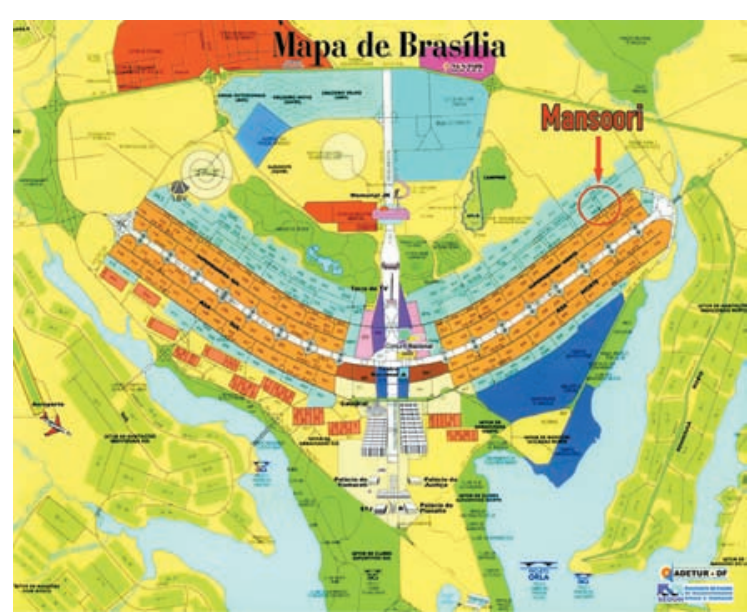

Город Чандигарх - зримое воплощение перспектив и результатов западно-восточного культурного синтеза, принципов и установок профессиональной и народной культуры. Подобная методика заостряла восприятие инонациональными архитекторами перспектив обновления историко-культурного наследия в контексте современности, обогатив его творческий потенциал, и, в конечном итоге, архитектуру модернизма.

\section{Бразилия}

Бесспорно, невозможно избежать сравнения Чандигарха с другим архитектурным феноменом тех лет - городом Бразилиа. В своей предвыборной программе президент Бразилии Ж. Кубичек (в ответ на будоражившие общество не одно десятилетие запросы политиков) предложил перенести столицу вглубь страны. Несмотря на сложную техническую и природную ситуацию - тропический климат, неосвоенные территории, джунгли, отсутствие транспортных путей, - город был создан в кардинально короткий срок - всего за четыре года.

Город Бразилиа вошел в анналы зодчества XX века. Архитектура новой национальной столицы - яркий пример футуристического подхода к решению её облика, желания заглянуть в далёкое будущее, что было стержневой идеей 0 . Нимейра, одного из «апостолов» модернизма [12, с. 68126]. Успех строительства определило единство проектного замысла авторского коллектива под его руководством, как в воплощении градоформирующих задач, так и разработке новаторских приёмов при решении уникальных объектов административно-правительственного центра. Градостроительную модель столицы в виде лука со стрелой (рис. 18) предложил Лючиа Коста - учитель 0. Нимейера. Вопросами ландшафта занимался архитектор Р.Б. Маркс.

Планировка города - максимально рациональна в целом и деталях. Симметричные дуги микрорайонов имеют простую для ориентации схему нумерации, расположения домов,

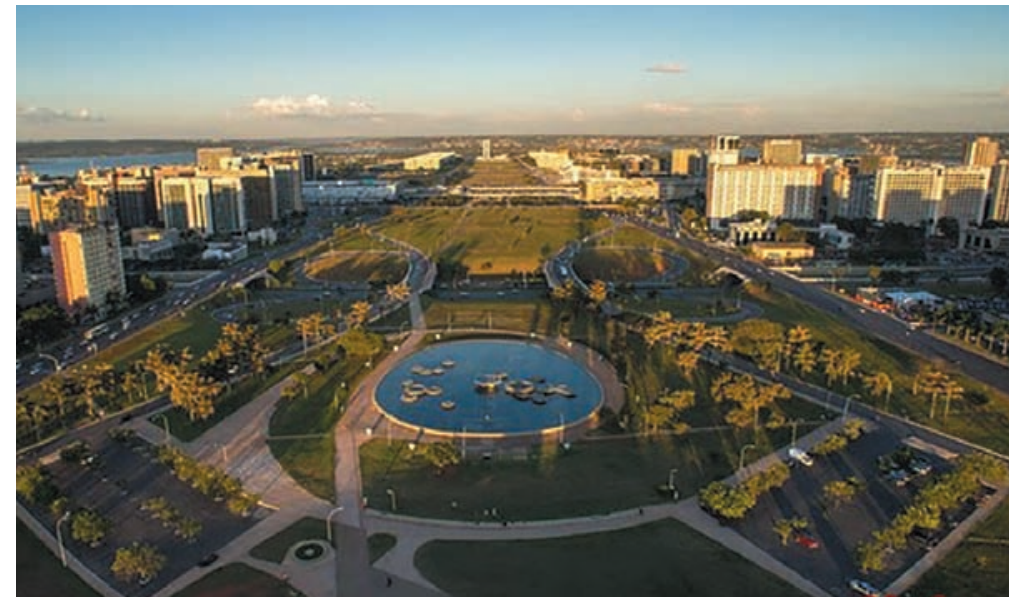

б) 
кварталов и даже типологической специализации проспектов, исходя из функции объектов: на одних улицах разместили банки, на других - магазины, аптеки, мастерские. 0. Нимейер декларировал идеал социальной гармонии жизнеустройства города Бразилиа - равенство горожан, их существование в едином пространстве без разделения на элитные и бедные кварталы [13, с. 395]. Безусловно, качество домостроения было дифференцировано, исходя из возможностей и запросов жильцов. Немаловажное значение придавалось объектам, связанным с духовно-гуманистическими параметрами жизни: необычный по архитектуре кафедральный собор («пучок» опор), Пантеон Отечества и Свободы, Комплекс библиотеки, Национальный музей (рис. 19 г, 20).

Стремясь преодолеть монотонность при застройке кварталов однотипными, модернистской стилистики жилыми домами, авторы проекта городской инфраструктуры использовали обширные массивы озеленения, продуманную систему дорог, многоуровневых развязок, свободных от светофоров улиц (см. рис. 18 б). Для улучшения внутриквартальных связей вы- полнили проходы под зданиями, поднятыми на опоры (приём нашёл применение и на крупных объектах). Это обеспечило движение горизонтальных потоков; вертикальную аэрацию создавал перепад между внутриквартальными температурами и нагретыми внешними пространствами.

Решающую роль в улучшении микроклимата, защите города от жарких ветров сыграло искусственное озеро Параноа (площадь $80 \times 5$ км), плавными дугами замыкающее контуры городских кварталов. В мировой практике подобная концепция организации городского пространства была одним из первых опытов биоклиматического проектирования (наряду с Чандигархом). У Оскара Нимейера вода выступала и своеобразным образным приёмом. Бассейны Дворца Рассвета (Алворада) не только дублируют конструктивные элементы здания, зрительно усиливая их, но и добавляют белым конструкциям цветосветовые характеристики - блики неба, вечерних огней. Вода каскадом льётся и с полуарок на фасаде Дворца Правосудия, что визуально смягчает строгий абрис остекленного фасада параллелепипеда здания (рис. 19 в).

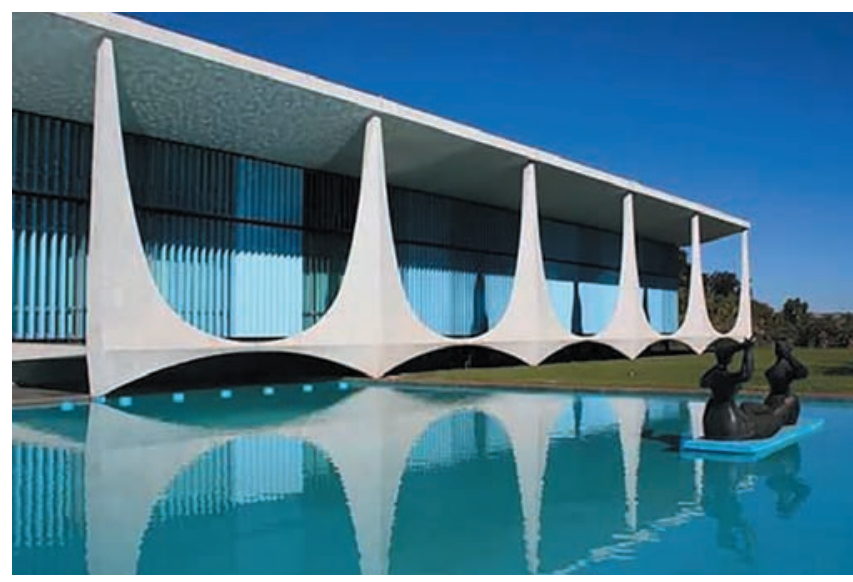

б) a)

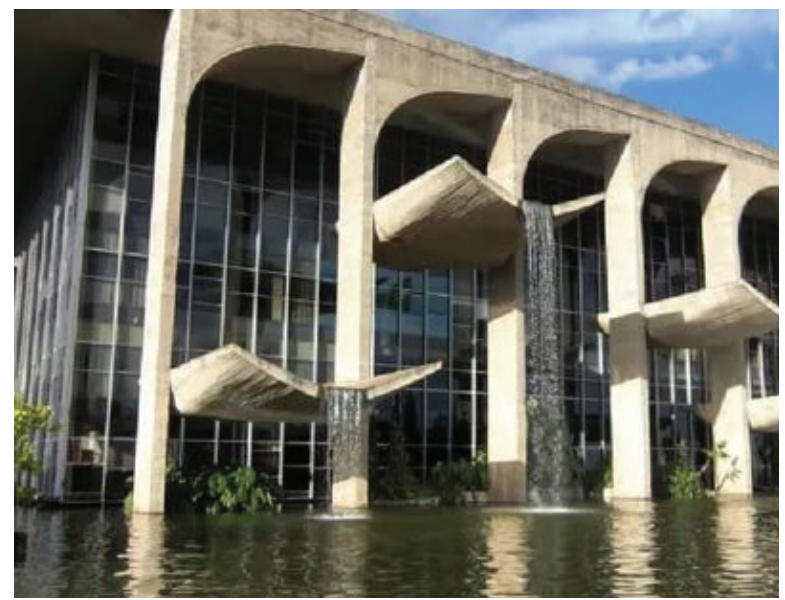

B)

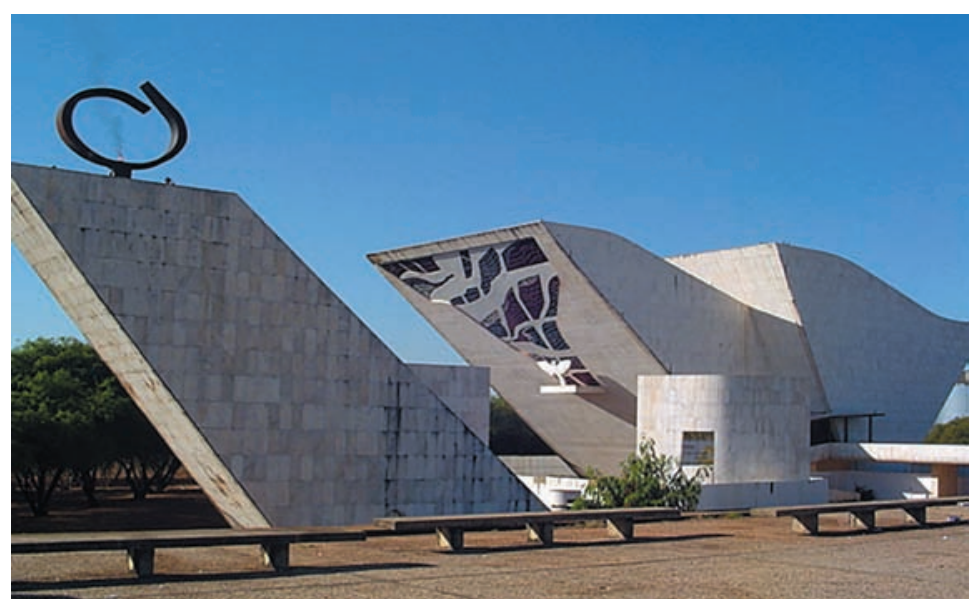

2)

Рис. 19. Комплекс площади Трёх Властей. Город Бразилиа. Архитектор Оскар Нимейер: а) Дворец Национального конгресса, 27-этажные спаренные корпуса секретариата Президентской администрации. Перспектива. 1960 год; б) Дворец Рассвета. Перспектива. 1957 год; в) Дворец Правосудия. Общий вид. 1970 год; г) Пантеон Отечества и Свободы. 1986 год 
Высотная доминанта столицы - 27-этажные спаренные корпуса здания Национального конгресса на площади Трёх властей (законодательной, исполнительной, судебной). Примыкающая платформа имеет эффектное завершение в виде двух чаш: с куполом над Палатой депутатов и контрастного перевёрнутого объёма амфитеатра для заседаний Федерального сената. Пилоны Дворца президента поддерживают большого

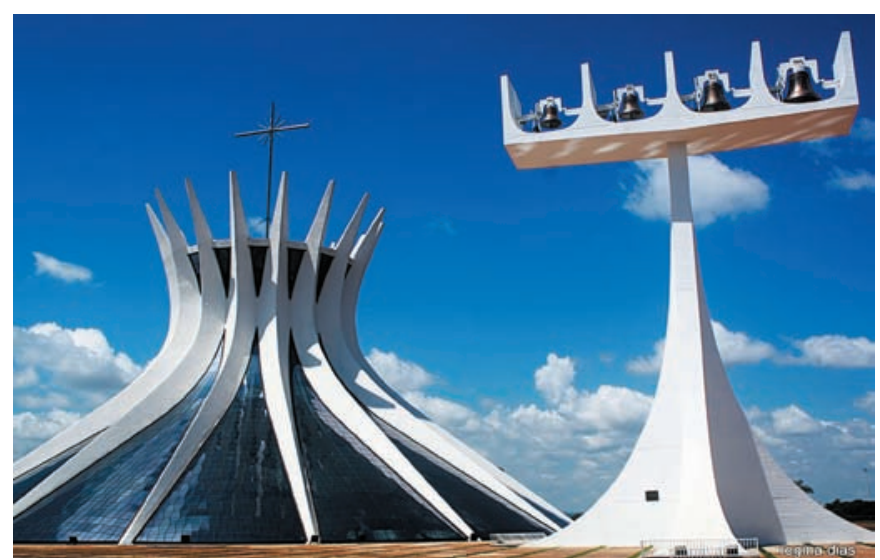

a)

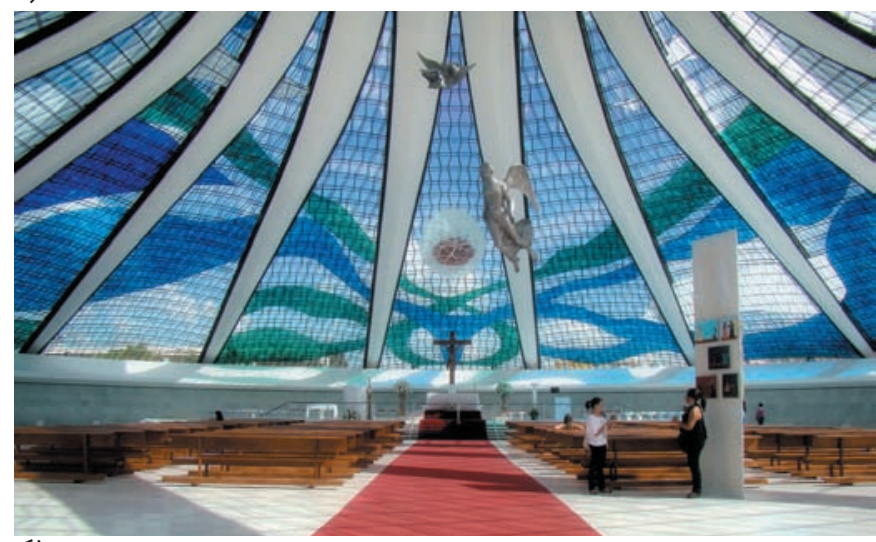

б)

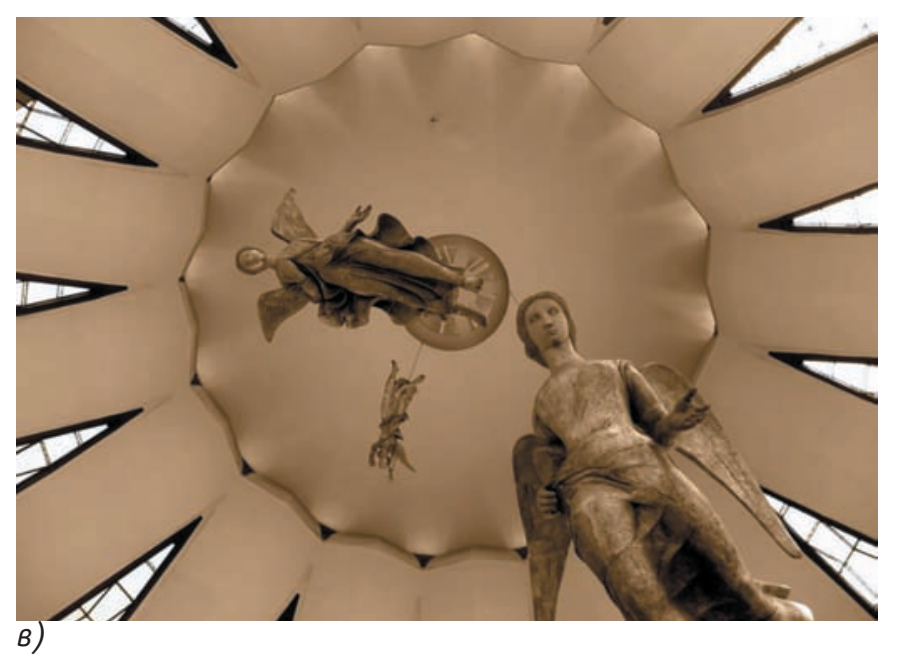

Рис. 20. Кафедральный собор. Город Бразилиа. Архитектор Оскар Нимейер. 1960-1970 годы: а) перспектива здания; б) интерьер - витражи и скульптуры купола («небесного свода»); в) завершение купола со скульптурами евангелистов и ангелов. Скульптор А. Сескьяти выноса кровлю, затеняющую стеклянные плоскости фасадов. Аналогичные опоры были использованы и во Дворце Плоскогорья (Планалту), а в дальнейшем они были растиражированы архитекторами многих стран, играя для профессионалов, по существу, роль современного ордера (рис. 19 a, б).

На потребителя архитектура города оказала несколько иное воздействие. Особенно на начальном этапе явно сказывался эмоционально-психологический дискомфорт в восприятии «одномоментно» создаваемых комплексов, их индифферентность к историческому наследию. Хотя 0. Нимейер, предвидя подобные обвинения, утверждал, что обращался к национальному барокко, взяв не архаизм декора, но логику конструктивных линий $[14$, с. 26]. В «лунных» пейзажах оказалось неуютно жить, да и туристы отмечают - «скучный город». Со временем в какой-то мере ситуацию спасла разросшаяся зелень, придав столице ощущение обжитости. Пространственный максимализм Бразилиа, тем не менее подавляет ${ }^{12}$, как и рациональный геометризм уникальных объектов. В отличие от их аскетичности, в поздних сооружениях, поэтически названных одним из критиков «кривые времени», 0. Нимейер смог блестяще выявить образно-пластические возможности бетона, усиленные цветовыми акцентами и отражениями в водоёмах, дублирующими объемами. Всё это придаёт буквально скульптурное совершенство конструктивно сложным решениям крупных зданий, словно бросающих вызов земному притяжению ${ }^{13}$ (рис. 21).

\section{***}

Творческая концепция городских пространств Чандигарха и Бразилиа, а также их составляющих в жилых комплексах и уникальных сооружениях, не только создала с восторгом воспринимаемую архитектурную среду, но, по существу, материализовала социальную утопию на новых координатах жизнестроения наций, вернее, их будущего. Ну, а с точки зрения профессиональных достижений, опыт строительства дал авторам проектов великолепный шанс самовыражения, творческого роста в масштабном и значимом социокультурном контексте молодых национальных школ. Единые в стилевом отношении ансамбли новых столиц со временем стали объектом не только национального, но и мирового культурного наследия модернизма.

В параметрах реализации личной концепции архитекторы зримо продемонстрировали два вектора новаторской архитектуры XX века: Ле Корбюзье утверждал приоритет

\footnotetext{
12 Жилые кварталы рассекает пустынная шестикилометровая эспланада правительственного центра, завершенная циклопическими маршами лестниц у озера. Столь удручающий приём был использован проектировщиками после землетрясения в Ташкенте, аналогично - в Ашхабаде. Раскалённое летом пространство гигантских площадей пешеходы преодолевали по периметру, прячась в тени зданий. Один из журналистов охарактеризовал ситуацию: «Эспланада для одиноко бредущего пешехода».

${ }^{13}$ Музей 0. Нимейера («Музей Глаза», 2002) при всей визуальной лёгкости имеет уникальные объемно-пространственные и конструктивные характеристики: площадь зала - 152 кв. м, с опорой на колонну высотой 18 м.
} 
функциональности, а для 0. Нимейера, решающими были красота и образность. Блестящее владение им инженерноконструктивными и пластическими возможностями современных материалов и технологий придавало форме сооружений доминирующее значение.

\section{Лuтература}

1. Крузман, Ю. Особая архитектура пятого континента // BERLOGOS. Интернет-журнал о дизайне и архитектуре. - Режим доступа: http://berlogos.ru/article/osobaya-arhitekturapyatogo-kontinenta/ (дата обращения 15.04.2020).

2. Кузнецова, М.В. Канберра. В поисках образа идеального города [Электронный ресурс] / М.В. Кузнецова // CiberLeninka. Научная электронная библиотека. - Режим доступа: https://cyberleninka.ru/article/n/kanberra-v-poiskahobraza-idealnogo-goroda/viewer (дата обращения 10.03.2020).

3. Эбинизер, Хоуардъ. Города будущего / Эбинизер Хоуардъ. - СПб : Типография товарищества «Общественная польза», 1911. - 177 c.

4. Косинский, А.С. Архитектурная форма в зависимости от факторов места и времени (на примере авторских работ 19601980-х годов): Автореф. дис. ... канд. архит. - М., 1984. - 25 с.

5. Топ 10: «Зелёная» архитектура // Architect/ - Режим доступа: https://thearchitect.pro/ru/news/4728-TOP_10_ Zelenaja_arhitektura (дата обращения 10.03.2020);

6. Земляная архитектура //AD. - Режим доступа: https:// www.admagazine.ru/architecture/zhiloj-kompleks-v-avstralii (дата обращения 04.04.2020); Земляной дом в Австралии // www.magazindomov.ru/. - Режим доступа: http://www. magazindomov.ru/2010/11/08/zemlyanoj-dom-v-avstralii/ (дата обращения 05.04.2020).

7. «В Австралии есть подземный город, где живут 2000 человек!» // SuperMegaShow.ru. - Режим доступа: https:// supermegashow.ru/v-avstralii-est-podzemnij-gorod-gde-zhivut2-000-chelovek-nichego-sebe-smotrite-video/?fbclid=IwAR2rH 8nelx0t0ME6j-2QuvbhnWxyf5pIFpdXEsU7s8siB8V2AF2tPxF03n0 (дата обращения 01.06.2020).

8. About Laka // Laka. - Режим доступа: https://lakareacts. com/about-laka/ (дата обращения 14.04.2020); Laka Competition 2018: архитектура, которая реагирует // www. archi.ru. - Режим доступа: https://archi.ru/contests/15659/laka-competition-2018arkhitektura-kotoraya-reagiruet (дата обращения 15.04.2020).

9. Малиновская, Е.Г. Формирование профессиональной архитектуры Казахстана. Дис. ... канд. искусствоведения. В 3-х т.: T. 2. - M., 1989. - C. 109; Malinovskaya, E. Young national schools of the XX century: Cultural identity or conceptual choice? [Электронный ресурс] // Proceedings of the 2017 International Conference on Art, Education and Humanities Research // «Atlantis Press» (Paris. France). - Режим доступа: https://www. atlantis-press.com/proceedings/icelaic-17/authors //http:// www.icelaic.org/2017// (дата обращения 10.03.2020).

10. Глушков, Д. Город Чандигарх. Архитектура независимости [Текст] / Д. Глушков // project Bauhaus. Архитектура и

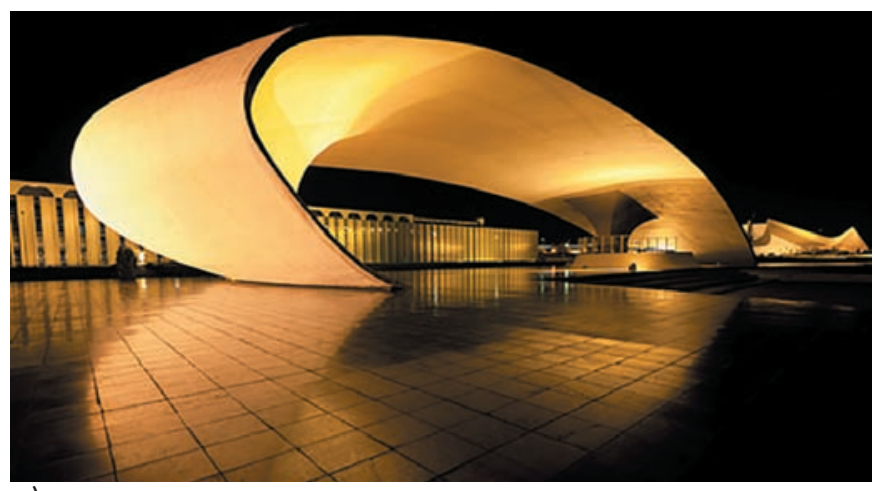

a)

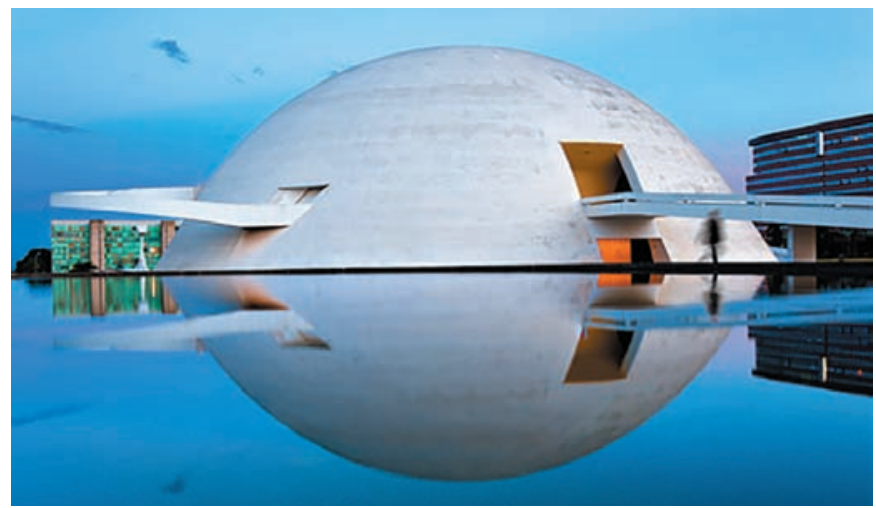

б)

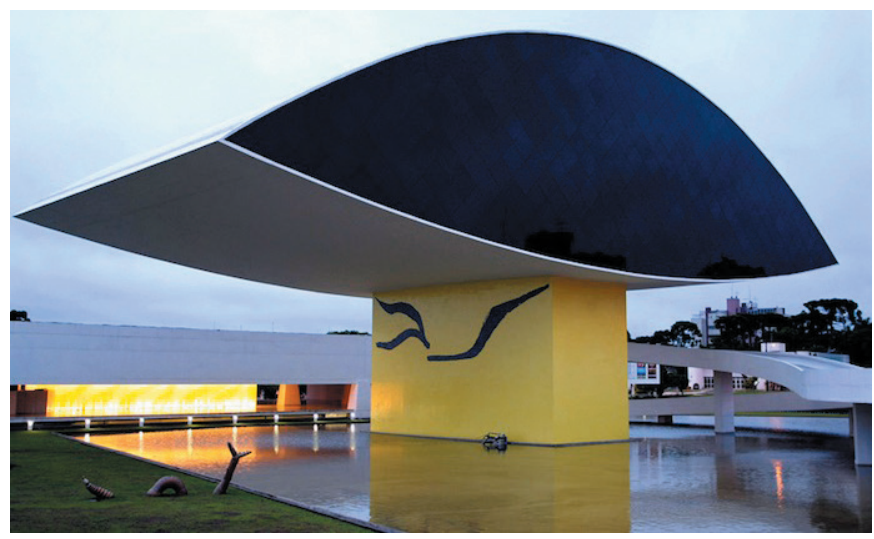

B)

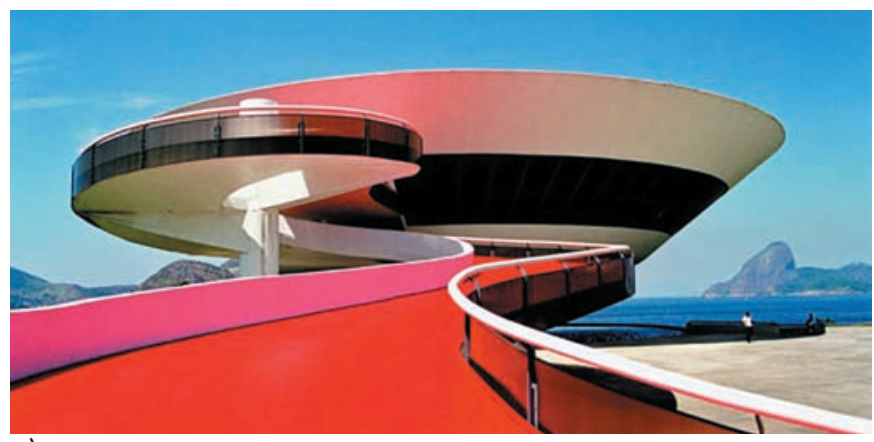

2)

Pис. 21. Архитектор Оскар Нимейер: а) Министерство обороны. Город Бразилиа. 1974 год; б) Национальный музей. Город Бразилиа. 2006 год; в) Музей Оскара Нимейера («Музей Глаза»). Город Бразилиа. 2002 год; г) Музей современного искусства. Бразилия. Рио-де-Жанейро (Нитерой). 1996 год 
дизайн. - Режим доступа: http://probauhaus.ru/chandigarhcity-architecture/ (дата обращения21.03.2020).

11. Короцкая, А.А. Современная архитектура Индии / А.А. Короцкая. - М. : Стройиздат, 1986. - 254 С. - С. 169-176.

12. Хайт, В.Л. Оскар Нимейер / В.Л.Хайт. - М. : Стройиздат, 1986. - 204 С. - С. 68-126.

13. Локтев, В.И. Оскар Нимейер / В.И. Локтев // Мастера архитектуры об архитектуре. Зарубежная архитектура. Конец XIX-XX век. - М. : Искусство, 1972. - С. 395.

14. Нимейер, О. Архитектура и общество / О. Нимейер. - М. : Прогресс, 1975. - 192 с.

\section{References}

1. Kruzman Yu. Osobaya arkhitektura pyatogo kontinenta [Special architecture of the fifth continent] // BERLOGOS. Internet-zhurnal o dizaine i arkhitekture. - Access mode: http:// berlogos.ru/article/osobaya-arhitektura-pyatogo-kontinenta/ (Accessed 15.04.2020).

2. Kuznetsova M.V. Kanberra. V poiskakh obraza ideal'nogo goroda [Canberra. In search of the image of an ideal city]. Cyberleninka Nauchnaya Elektronnaya biblioteka [CiberLeninka. Scientific Digital library]. Access mode: https://cyberleninka.ru/ article/n/kanberra-v-poiskah-obraza-idealnogo-goroda/viewer (Accessed 10.03.2020).

3. Ebinizer Khouard. Goroda budushchego [Cities of the Future]. Saint Petersburg, Printing house of the partnership "Public Benefit" Publ., 1911, 177 p.

4. Kosinskii A.S. Arkhitekturnaya forma $v$ zavisimosti ot faktorov mesta i vremeni (na primere avtorskikh rabot 19601980-kh godov): Avtoref. dis. ... kand. arkhit. [Architectural form depending on the factors of place and time (on the example of copyright works of the 1960-1980s): Abstract. dis. ... cand. Architect.]. Moscow, 1984, 25 p.

5. Top 10: «Zelenaya» arkhitektura ["Green" architecture"]. Architect. Access mode: https://thearchitect.pro/ru/news/4728TOP_10_Zelenaja_arhitektura (Accessed 10.03.2020).

6. Zemlyanaya arkhitektura [Earth architecture]. AD. Access mode: https://www.admagazine.ru/architecture/zhilojkompleks-v-avstralii (Accessed 04.04.2020); Zemlyanoi dom $\checkmark$ Avstralii [Earthen house in Australia]. www.magazindomov. ru. Access mode: http://www.magazindomov.ru/2010/11/08/ zemlyanoj-dom-v-avstralii/ (Accessed 05.04.2020).

7. «V Avstralii est' podzemnyi gorod gde zhivut 2000 chelovek!» [Australia has an underground city with 2000 people!]. SuperMegaShow. ru. Access mode: https://supermegashow.ru/v-avstralii-est-podzemnijgorod-gde-zhivut-2-000-chelovek-nichego-sebe-smotrite-video/ ?fbclid=IwAR2rH8nelx0t0ME6j-2QuvbhnWxyf5pIFpdXEsU7s8siB8V2AF2tPxF03n0 (Accessed 01.06.2020).

8. About Laka. Laka. Access mode: https://lakareacts. com/about-laka/ (Accessed 14.04.2020); Laka Competition 2018: arkhitektura, kotoraya reagiruet [Laka Competition 2018: architecture that responds]. www.archi.ru. Access mode: https:// archi.ru/contests/15659/laka-competition-2018-arkhitekturakotoraya-reagiruet (Accessed 14.04.2020).

9. Malinovskaya E.G. Formirovanie professional'noi arkhitektury Kazakhstana. Dis. ... kand. Iskusstvovedeniya [Formation of professional architecture of Kazakhstan. Dis. ... cand. art history]. In 3 vol. Vol. 2. Moscow, 1989, 109 p; Malinovskaya E. Young national schools of the XX century: Cultural identity or conceptual choice? Proceedings of the 2017 International Conference on Art, Education and Humanities Research. «Atlantis Press» (Paris. France). Atlantis Press. Access mode: https://www.atlantis-press.com/proceedings/ icelaic-17/authors(Accessed 10.03.2020); Icelaik-2020. Access mode: http://www.icelaic.org/2017// (Accessed 10.03.2020).

9. Glushkov D. Gorod Chandigarkh. Arkhitektura nezavisimosti [City of Chandigarh. Architecture of Independence]. Project Bauhaus. Arkhitektura i dizain. Access mode: http://probauhaus. ru/chandigarh-city-architecture/ (Accessed 21.03.2020).

10. Korotskaya A.A. Sovremennaya arkhitektura Indii [Modern architecture of India]. Moscow, Stroiizdat Publ., 1986, 254 p., pp. 169-176.

11. Khait V.L. Oskar Nimeier. Moscow, Stroiizdat Publ., 1986, 204 p., pp. 68-126.

12. Loktev V.I. Oskar Nimeier. Mastera arkhitektury ob arkhitekture. Zarubezhnaya arkhitektura. Konets XIX-XX vek [Masters of architecture about architecture. Foreign architecture. The end of the XIX - XX centuries]. Moscow, Iskusstvo Publ., 1972, 395 p.

13. Nimeier 0. Arkhitektura i obshchestvo [Architecture and Society]. Moscow, Progress Publ., 1975, 192 p.

Малиновская Елизавета Григорьевна (Алматы, Казахстан). Кандидат искусствоведения, доцент. Директор картинной галереи «ARK» (050051, Казахстан, Алматы, б/ц «Достар», пр. Достык 240, оф. 107). Эл. почта: eliz.mln@gmail.com.

Elizaveta G. Malinovskaya (Almaty, Kazakhstan ). PhD in Art Science, Docent Art Gallery «ARK». Director (of. 107, 240 Dostyk Ave., ‘Dostar'Business Center, Almaty, Kazakhstan, 050051).E-mail: eliz.mln@gmail.com 